\title{
Macroscopic, optical and diffraction assessment of encrustations and SEM analyses of phototrophic microbial mats from wellheads and select zones of emergence of mineral water in Serbia
}

\author{
Vladimir Šaraba1*, Slađana Popović ${ }^{2}$, Vesna Obradović3 ${ }^{3}$ Jana Štrbački ${ }^{1}$, Violeta Gajić ${ }^{4}$, \\ Predrag Vulić ${ }^{4}$, Gordana Subakov Simić ${ }^{5}$ and Olivera Krunić ${ }^{1}$ \\ ${ }^{1}$ University of Belgrade, Faculty of Mining and Geology, Department of Hydrogeology, Đušina 7, 11000 Belgrade, Serbia; \\ (*corresponding author: vladimirsarabaa@gmail.com) \\ 2 University of Belgrade, Institute of Chemistry, Technology and Metallurgy, National Institute, Department of Ecology and Technoeconomics, Njegoševa 12, \\ 11000 Belgrade, Serbia \\ 3 Jaroslav Černi Water Institute, Jaroslava Černog 80, 11000 Belgrade, Serbia \\ ${ }^{4}$ University of Belgrade, Faculty of Mining and Geology, Department of Mineralogy, Crystallography, Petrology and Geochemistry, Đušina 7, \\ 11000 Belgrade, Serbia \\ ${ }^{5}$ University of Belgrade, Faculty of Biology, Department of Algology, Mycology and Lichology, Studentski trg 16, 11000 Belgrade, Serbia
}

doi: $10.4154 / g c .2019 .09$

\section{Article history:}

Manuscript received October 26, 2018 Revised manuscript accepted February 15, 2019 Available online June 4, 2019
Keywords: mineral water, encrustations, phototrophic microbial mats, macroscopic and optical assessment, SEM analyses, X-ray powder diffraction, hydrogeochemical modeling

\begin{abstract}
Investigations focusing on wellhead encrustations within select zones of emergence of mineral water, in different hydrogeological provinces, were conducted from 2014 to 2017 in Serbia. They included: well BB-1 in Bogatić (Inner Dinaric Alps of western Serbia), wells LB-4 and LB-5 in Lukovska Banja (Šumadija-Kopaonik-Kosovo Province), and wells VG-2 and VG-3 in Vranjska Banja (Serbian Crystalline Core). The studied occurrences belong to the group of hot mineral waters, with temperatures ranging from $62^{\circ} \mathrm{C}$ to $93.9^{\circ} \mathrm{C}$, and total dissolved solids (TDS) from 600 to $1267 \mathrm{mg} / \mathrm{L}$. They are mildly acidic to mildly alkaline $(\mathrm{pH} 6.6-8.0)$ and their genetic types are $\mathrm{HCO}_{3}{ }^{-}-\mathrm{Na}^{+}+\mathrm{K}^{+}$(Bogatić and Lukovska Banja) and $\mathrm{SO}_{4}{ }^{2-}, \mathrm{HCO}_{3}{ }^{-}-\mathrm{Na}^{+}+\mathrm{K}^{+}$(Vranjska Banja). Macroscopic, optical and diffraction assessment revealed that the encrustations comprised calcite and aragonite minerals, along with some local quartz, muscovite, albite and clinochlore. The conclusion was that there was a predominant presence of calcium carbonate in all the occurrences, represented by crystalline calcite grains, characteristically birefractive, and dark, semitranslucent grains in the form of microcrystalline calcite highly stained by iron hydroxides (Bogatić), as well as crystalline calcite with radially developed carbonate - aragonite (Lukovska Banja) and rod-like and filamentous aggregates of aragonite and calcite, highly translucent in places (Vranjska Banja).The texture of the samples exhibits alternating horizontal or wavy carbonate laminae. In Vranjska Banja, they include thin micritic to medium crystalline laminae and laminae composed of aggregates of aragonite needles in the form of bunch. In Bogatic and Lukovska Banja, there are thick micritic and highly porous laminae, 0.025 to $1 \mathrm{~mm}$ thick, or interlayers of a coarser crystalline structure. Apart from encrustations, all the occurrences exhibit phototrophic microbial mats, which were analyzed by scanning electron microscopy. The onset and progress of encrustation are primarily influenced by the physical and chemical composition of the mineral water (T, pH, TDS, $\mathrm{HCO}_{3}{ }^{-}, \mathrm{Ca}^{2+}, \mathrm{CO}_{2}$, etc.), as corroborated by hydrogeochemical modeling software PHREEQC 3.4.0. In addition, phototrophic biofilms might be contributing to the creation and accumulation of minerals in the encrustations.
\end{abstract}

\section{INTRODUCTION}

In Serbia to date, encrustations have frequently been noted on the technical elements of mineral water wells (wellheads, screens, pumps, discharge pipes, and the like) (LAZIĆ, 2004), as well as within zones of emergence (PROTIĆ, 1995; ŠARABA et al., 2017).

Encrustations are typical only of the upper part of the well casing, caused by a higher flow velocity in that region (HOUBEN \& WEIHE, 2010).

Encrustations are precipitates of salts and alkalis, which most frequently takes place in mineral waters from aquifers with dissolved calcium, magnesium and iron. Precipitation is the result of a change in ambient conditions ( $\mathrm{pH}$, temperature, pressure, solute concentration) due to mineral water pumping, which causes super- saturation of the solution and the formation of encrustations (PAPIĆ, 1999; HOUBEN, 2000; HOUBEN, 2001; GARCIA et al., 2005; de ZWART, 2007; DRAGIŠIĆ \& POLOMČIĆ, 2009). Encrustation of the technical components of wells is non-uniform (HOUBEN, 2006), with more intensive precipitation on smooth than rough surfaces (DRISCOLL, 1986; HOUBEN \& TRESKATIS, 2007).

The main drivers of encrustation formation (PAPIĆ, 1999; VAN BEEK, 2011): (i) dissolution, creating suspended substances, (ii) transport of dissolved substances, and (iii) precipitation of dissolved substances.

The hydrodynamic parameters of mineral water, which facilitate encrustation, include changes from laminar to turbulent flow and discharge via an overflow or groove (PAPIĆ, 1999; HOUBEN \& TRESKATIS, 2007). 

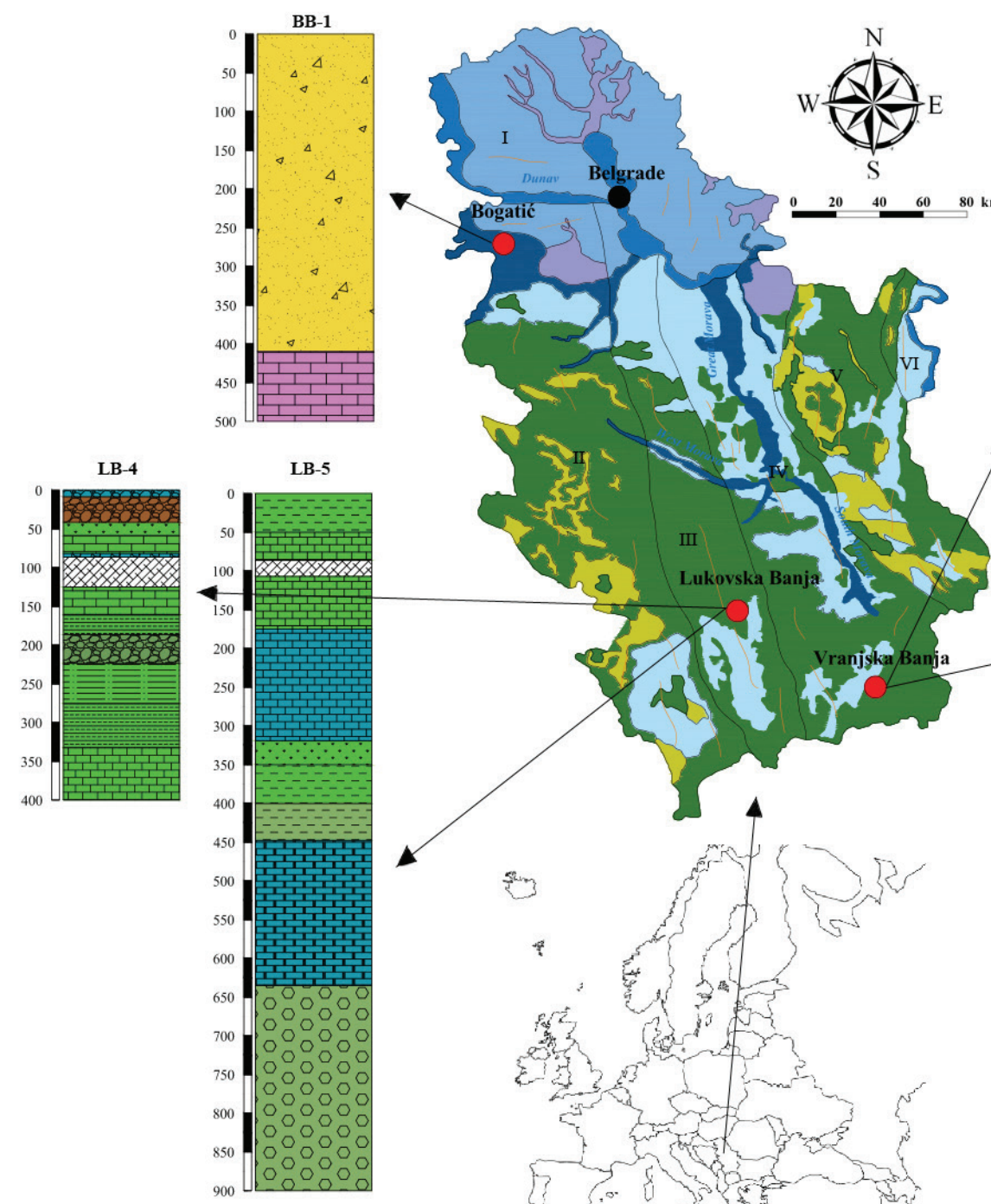

GEOLOGICAL LEGEND
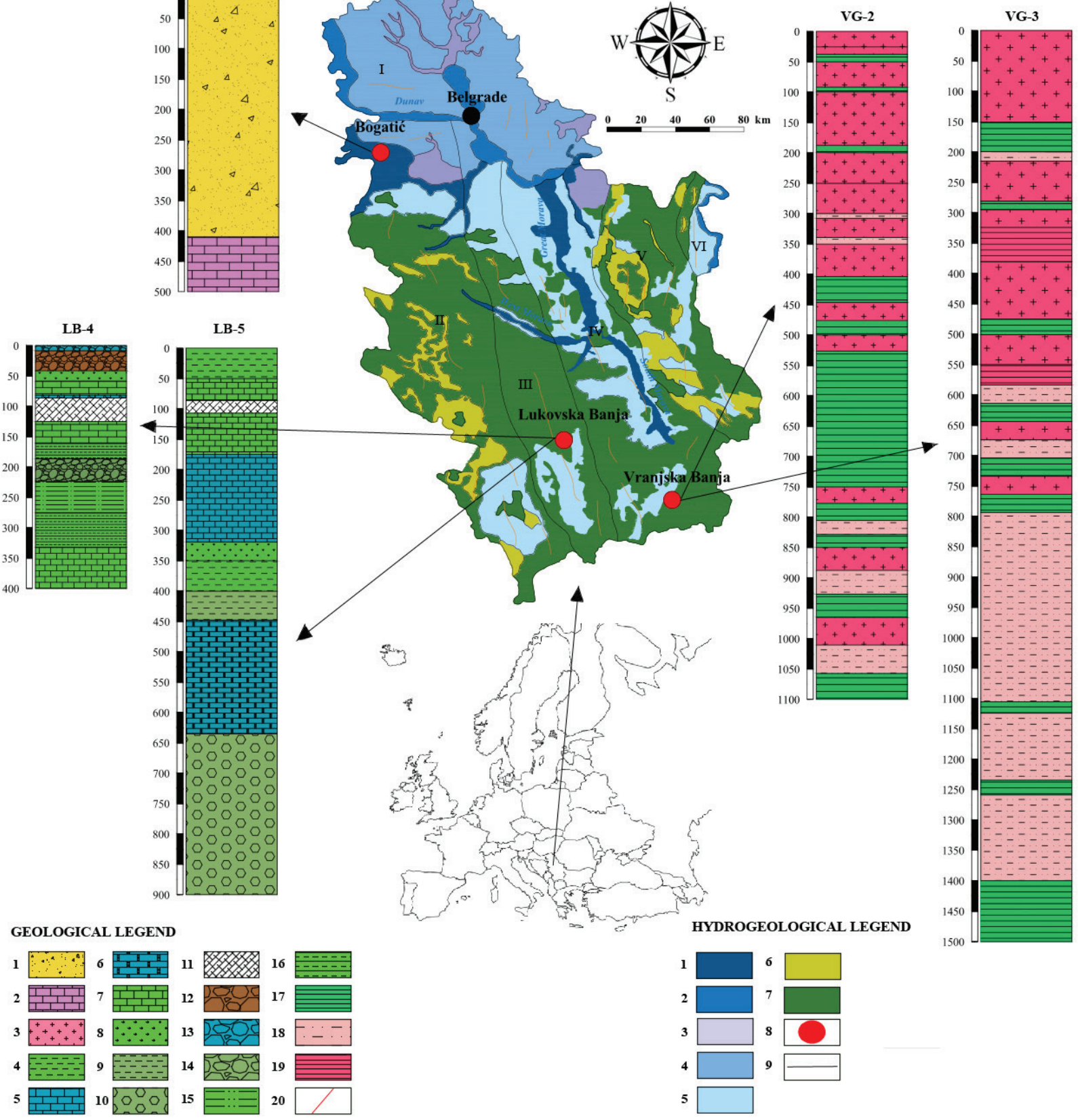

Figure 1. Schematic representation of the studied mineral water sites on the hydrogeological map of Serbia, including geologic columns (FILIPOVIĆ et al., 2005; modified).

Geological legend: 1 - Medium-grain gravel, gravelly clays, sand, sandstones, conglomerates, debris, tuffs, marls and Neogene limestones; 2 - Tertiary limestones; 3 - Compact and fractured granodiorites; 4 - Sandstones and marls, alternating marls, marly limestones and sandstones; 5 - Sandstones, limestones and marls; 6 - Carbonate rocks with chert, pyrite and quartz; 7 - Limestones, limestones with quartz; 8 - Diabases and spilites; 9 - Carbonate rocks with chert and pyrite; 10 - Serpentinites; 11 - Hydrothermally altered rocks; 12 - Heterogeneous agglomeratic material; 13 - Agglomeratic, unconsolidated material; 14 - Peridotbreccias; 15 - Chloritic rocks; 16 - Marls, occasional limestones; 17 - Schistose metamorphic rocks; 18 - Muscovite-biotite gneisses; 19 - Silicate-amphibole schists, with quartzite interbeds; 20 - Fault.

Hydrogeological legend: Hydrogeological provinces: I - Pannonian Plain; II - Inner Dinarides of western Serbia; III - Šumadija-Kopaonik-Kosovo province; IV - Serbian Crystalline Core; V - Carpathian-Balkanide province; VI - Dacian Basin; 1 - Intergranular porosity (high conductivity); 2 - Intergranular porosity (medium conductivity); 3 - Intergranular porosity (low conductivity); 4 - Hydrogeologic complex: subartesian and artesian aquifers of the Neogene Pannonian Basin; 5 - Hydrogeologic complex: subartesian and artesian aquifers of smaller Neogene basins; 6 - Karst and karst-fractured porosity of high conductivity; 7 - Fractured porosity of low and medium conductivity (including parts of the terrain conditionally devoid of water); 8 - Occurences of mineral water; 9 - Hydrogeological boundary.

Encrustations often comprise chemical compounds of calcium, silicon, manganese, iron and phosphorus (HOUBEN, 2000; HOUBEN, 2001; HOUBEN \& TRESKATIS, 2007; WOYESSA, 2012). Calcium carbonate encrustations are the most frequent type encountered in mineral water extraction (BROWN, 2013). PROTIĆ (1995) reported similar findings, pointing out that cal- cium carbonate encrustations in the form of calcite veins, travertine, and calcite interactions in the soil and sedimentary rocks are often found in places of emergence of mineral waters in Serbia, corroborated by examples of select mineral water occurrences in Serbia where calcium carbonate encrustations have been detected. 
Table 1. Characteristics of the studied mineral water wells (MILIVOJEVIĆ, 1989; MARTINOVIĆ \& MILIVOJEVIĆ, 1998; KRUNIĆ, 1999; FILIPOVIĆ, 2003; FILIPOVIĆ et al., 2005; KRUNIĆ, 2012; MARTINOVIĆ, 2012).

\begin{tabular}{|c|c|c|c|c|c|c|c|}
\hline Locality & $\begin{array}{c}\text { Well } \\
\text { designation }\end{array}$ & $\begin{array}{l}\text { Type } \\
\text { of well }\end{array}$ & $\begin{array}{c}\text { Depth } \\
\text { of well }(m)\end{array}$ & Function & Lithology & $\begin{array}{l}\text { Type of aquifer and } \\
\text { hydrodynamic characteristic }\end{array}$ & $\begin{array}{l}\text { Yield } \\
(\mathrm{L} / \mathrm{s})\end{array}$ \\
\hline Bogatić & BB-1 & \multirow{5}{*}{ Drilled } & 470 & $\begin{array}{l}\text { Heating of residential } \\
\text { buildings and hot houses }\end{array}$ & Triassic limestone & Karst, confined & 37.5 \\
\hline \multirow{2}{*}{$\begin{array}{l}\text { Lukovska } \\
\text { Banja }\end{array}$} & LB-4 & & 401 & $\begin{array}{l}\text { Health-and-recreation, } \\
\text { heating of buildings; }\end{array}$ & Cretaceous limestone & Karst-fractured, confined & 4.7 \\
\hline & LB-5 & & 870 & $\begin{array}{l}\text { Health-and-recreation, } \\
\text { heating of buildings; }\end{array}$ & Cretaceous limestone & Karst-fractured, confined & 4.6 \\
\hline \multirow{2}{*}{$\begin{array}{l}\text { Vranjska } \\
\text { Banja }\end{array}$} & VG-2 & & 1064 & $\begin{array}{l}\text { Health-and-recreation, } \\
\text { heating of buildings; }\end{array}$ & $\begin{array}{l}\text { Petrified granodiorite and gneiss- } \\
\text {-granite, amphibole-biotite schist }\end{array}$ & Fractured, confined & 26 \\
\hline & VG-3 & & 1470 & $\begin{array}{l}\text { Health-and-recreation, } \\
\text { heating of buildings; }\end{array}$ & $\begin{array}{l}\text { Petrified quartz-diorite, grandiorite, } \\
\text { with schist intercalations }\end{array}$ & Fractured, confined & 21 \\
\hline
\end{tabular}

The main feature of calcium carbonate is that in the presence of carbon dioxide it becomes a readily soluble compound. The solubility of calcium hydrogencarbonate is about $160 \mathrm{~g} / \mathrm{L}$. In the absence of carbon dioxide, the solubility of calcium carbonate decreases to only about $13 \mathrm{mg} / \mathrm{L}$. In addition, calcium carbonate exhibits retrograde solubility - as the temperature increases, the solubility decreases and vice-versa (PLUMMER \& BUSENBERG, 1982; OGINO et al., 1987; APELLO \& POSTMA, 2004).

Encrustations are almost always accompanied by various microbial processes (BUIK \& WIILEMSEN, 2006; DEED \& PREENE, 2015), represented by prototrophic biofilms in the selected occurrences of mineral water in Serbia. This was the main reason why they were analyzed.

Microbial activity in phototrophic mats can intensify encrustation, in which case the initial stage is small-scale encrustation, dominated by the biological component. Over time, minerals take over and become most of the encrusted mass (SCHNIEDERS, 2003; ŠARABA et al., 2017).

Phototrophic biofilms are considered to be the the earliest communities on planet Earth (TICE \& LOWE, 2006; NOFFKE et al., 2006). The life of microorganisms in phototrophic biofilms is limited by numerous ecological factors. Light is the basic factor for their growth (JEMCEV \& ĐUKIĆ, 2000), but also, among others, $\mathrm{pH}$ value, ionic activity and temperature are unavoidable (DONLAN, 2002; LI \& LOGAN, 2004). In most cases, microorganisms survive as long as they have sufficient resources for development and reproduction (LAWRENCE \& CALDWELL, 1987; SZEWZYK \& SCHINK, 1988; ŠARABA et al., 2017).

The study of encrustations at the selected mineral water occurrences in Serbia began with analysis of mineral deposits on the wellhead of well BB-1 at Bogatić, where the scale of encrustation was such that the discharge capacity of the well decreased from $60 \mathrm{~L} / \mathrm{s}$, measured in 1986 when the well was installed, to only $37.5 \mathrm{~L} / \mathrm{s}$, determined by pumping tests in 2014. Consequently, the well needed to be rehabilitated. The study was then extended to include a number of other wells. The objective was to detect and analyze encrustations and show that well BB-1 at Bogatić was not a solitary Serbian case. Additional sites included Lukovska Banja and Vranjska Banja which, like the mineral water occurrence at Bogatić, featured extremely high temperatures (above $60^{\circ} \mathrm{C}$ ) and $\mathrm{HCO}_{3}{ }^{-}-\mathrm{Na}^{+}+\mathrm{K}^{+}$as the basic ionic composition, along with some $\mathrm{SO}_{4}{ }^{2-}$ at Vranjska Banja. Apart from encrustations, phototrophic biofilms were detected in all the occurrences.

To date, encrustations of wellheads and zones of emergence of mineral water have not been the object of hydrogeological re- search in Serbia. The study focused on determining the mineral composition of encrustations by microscopic and optical assessment and X-ray powder diffraction. Another objective was to establish a correlation between the chemical composition of the mineral waters and the mineral composition of the encrustations through hydrogeochemical modeling, and to assess the propensity for encrustation by prognostic analyses.

\section{STUDY AREAS}

The studied occurrences are characterized by different structuralgeologic, historic-geologic, petrographic-mineralogic, hydrogeological and other properties. They are located in the hydrogeological provinces of the Inner Dinarides of western Serbia (the occurrence in Bogatić: well BB-1), the Šumadija-KopaonikKosovo Zone (the occurrence in Lukovska Banja: wells LB-4 and LB-5), and the Serbian Crystalline Core (the occurrence in Vranjska Banja: wells VG-2 and VG-3) (Fig. 1).

The hydrogeological provinces of Serbia have been delineated based on tectonic, lithofacies, geomorphological, hydrogeological, physico-geographic and other characteristics. They coincide with geotectonic units, albeit with differing boundaries, to greater or lesser extents (FILIPOVIĆ et al., 2005; KRUNIĆ, 2012) (Fig. 1).

The characteristics of the studied mineral waters are shown in Table 1.

\section{MATERIALS AND METHODS}

Investigations that focused on the encrustation of wellheads and selected zones of occurrence of mineral water were conducted from 2014 to 2017 in Serbia, at Bogatić (well BB-1), Lukovska Banja (wells LB-4 and LB-5) and Vranjska Banja (wells VG-2 and VG-3). SEM analyses of phototrophic biofilms were also performed.

Consistent with the set requirements and objectives of the study, the materials used and methods applied corresponded to the scope and sequence of the investigations as shown in Figure 2.

\subsection{Sampling of mineral waters}

Samples of mineral water for physical and chemical analyses were collected in plastic bottles. The bottles were sterile and the caps complied with international standards ISO 9001, ISO 14001 and OHSAS 18001. Prior to use, the bottles were rinsed and cleaned with a $1 \% \mathrm{HCl}$ solution, then flushed with distilled water. Upon sampling of mineral water, the bottles were capped to prevent leakage and then sealed with a nut. The bottles were labeled, indicating serial numbers and other important information, in- 
OCCURENCES OF MINERAL WATER

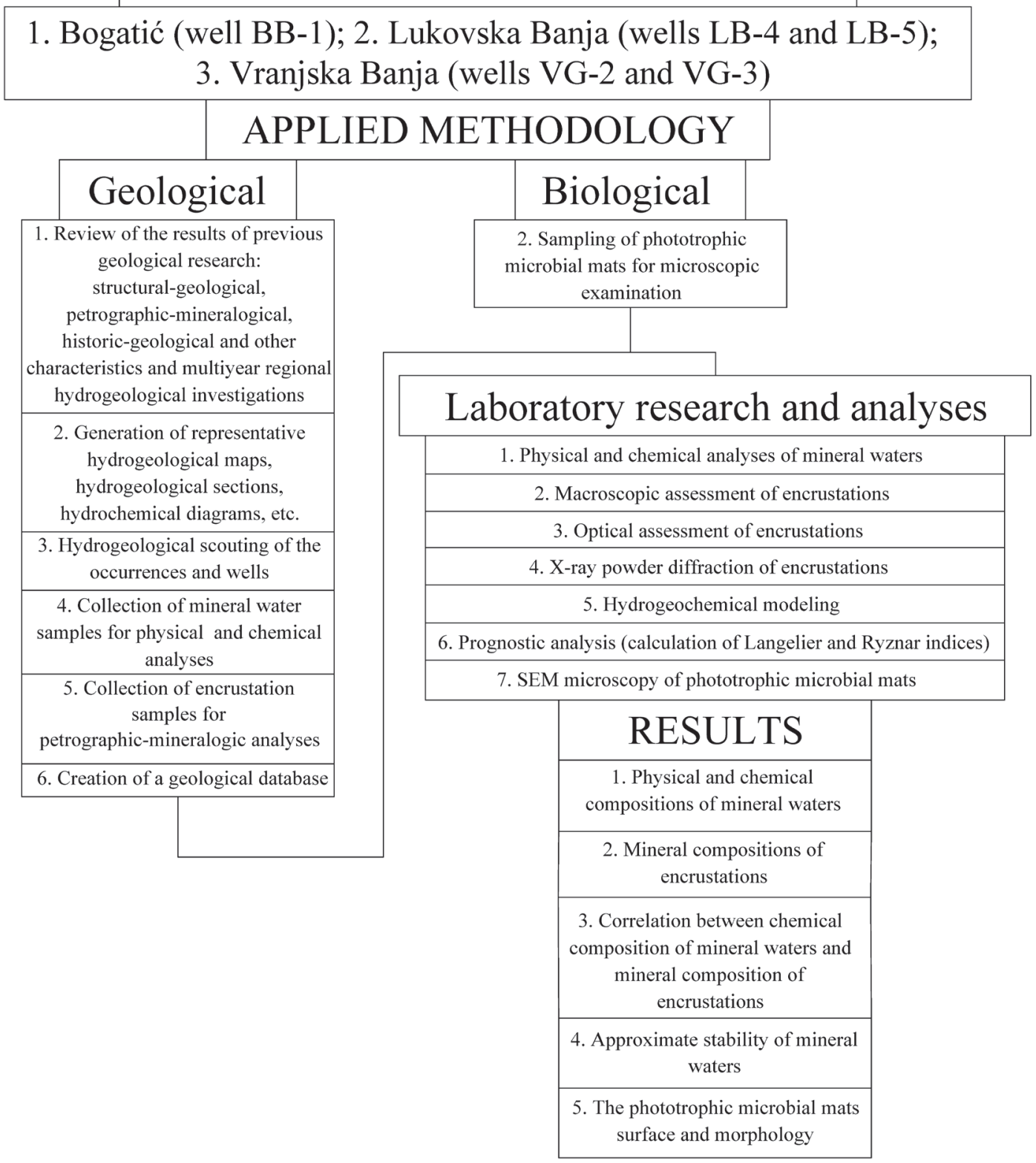

Figure 2. Algorithm of the applied methodology.

cluding the name of the sampling site, water temperature (T), $\mathrm{pH}$ and conductivity (EC).

\subsection{Sampling of encrustations}

Well ageing and the sampling points within the studied zones of emergence of mineral water are illustrated in Figure 3. Encrustations (Fig. 3) were sampled at Bogatić (the well BB-1), Lukovska Banja (wells LB-4 and LB-5) and Vranjska Banja (wells VG-2 and VG-3), and labeled after wells: BB-1, VG-2, VG-2* and VG3. Sample VG-2* was part of the sample VG-2. Samples from wells LB-4 and LB-5 at Lukovska Banja were pulverized at the same time for the X-ray powder diffraction assay and labeled LB. Hence, a total of five samples were tested (Fig. 4).

\subsection{Sampling of phototrophic microbial mats}

Mat samples were collected near the points of emergence of mineral water and at wellheads in Bogatić, Lukovska Banja and
Vranjska Banja (Fig. 3). Sampling sites with notable highly-developed and variously coloured biofilm were chosen for analysis by scanning electron microscopy. The samples were collected using a sterilized scalpel, placed in sterile plastic bottles and fixed with a $1.5 \%$ formaldehyde solution.

\subsection{Physical and chemical analyses of mineral waters}

The mineral water samples were delivered to the laboratory at the Public Health Institute of Belgrade, within the prescribed timeframe, for all the required physical and chemical analyses (Tab. 2).

The temperature (T), $\mathrm{pH}$ and conductivity (EC) of the mineral waters were determined in situ. CyberScan CON $510 \mathrm{pH}$ meter was used to determine $\mathrm{pH}$ levels and temperatures. This instrument could also be used to measure total dissolved solids (TDS). Conductometer HI98192 was used to measure conductivity. This instrument is equipped with a four-ring HI763133 conductivity electrode. 

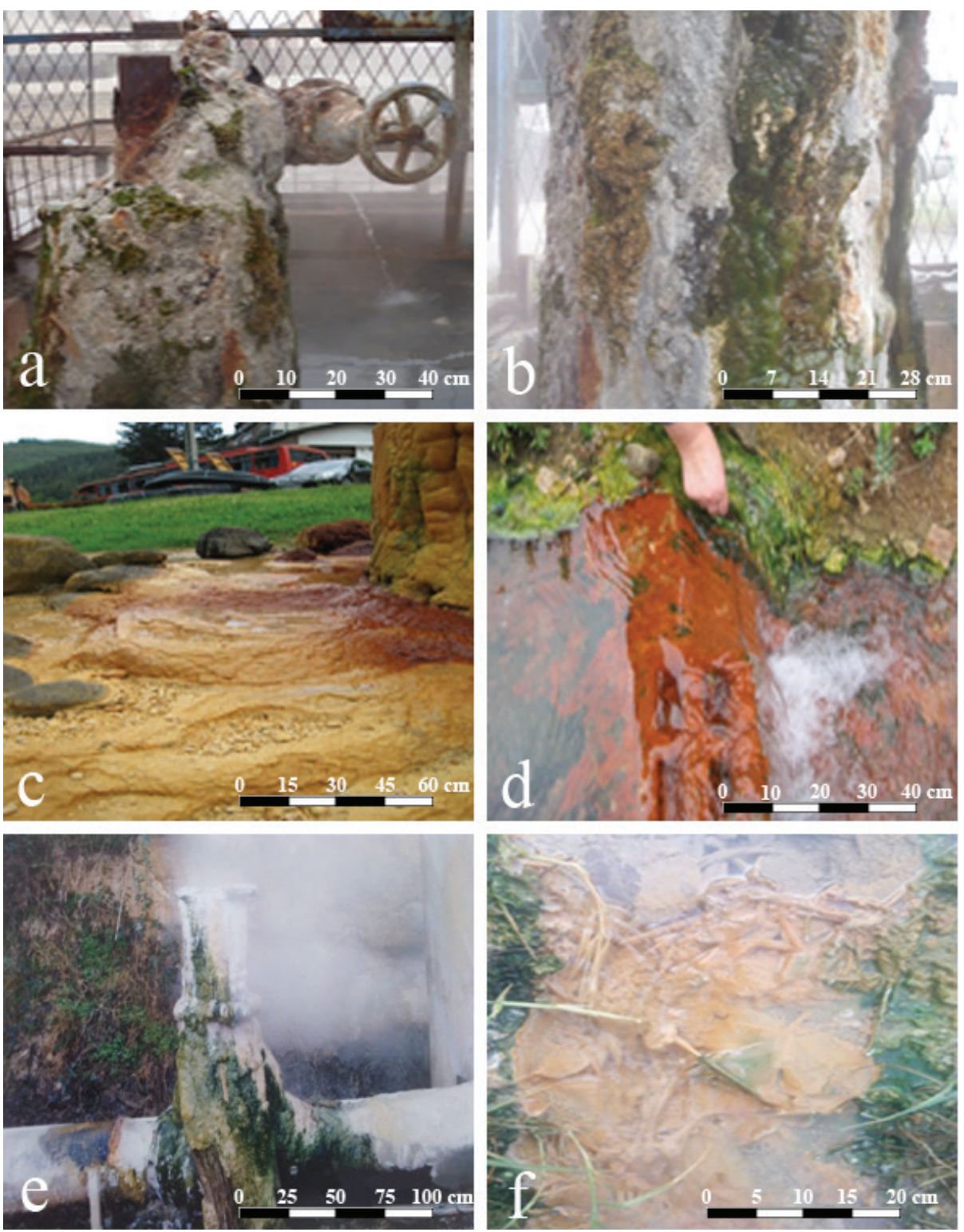

Figure 3. Condition of wells and points of sampling of phototrophic microbial mats and encrustations in the studied zones of occurrence of mineral water (photo: M. LAZIĆ, 2014-2017; V. ŠARABA, 2017). Legend: a, b. Bogatić; c, d. Lukovska Banja; e, f. Vranjska Banja.

The colour of the mineral water samples was determined colorimetrically (Pt-Co scale), gravimetry was used to determine TDS and volumetry to test the $\mathrm{KMnO}_{4}$ demand. With regard to macrocomponents, $\mathrm{Na}^{+}, \mathrm{K}^{+}, \mathrm{Ca}^{2+}, \mathrm{Mg}^{2+}$ were determined by AAS (Atomic Adsorption Spectrometry), $\mathrm{HCO}_{3}^{-}, \mathrm{Cl}^{-}$by the volumetric method, and $\mathrm{SO}_{4}{ }^{2-}$ by the turbidimetric method. The concentrations of $\mathrm{NH}_{4}^{+}, \mathrm{NO}_{3}{ }^{-}$and $\mathrm{NO}_{2}{ }^{-}$were established by means of UVVIS spectrophotometry, and silica concentrations by ICPOES spectrometry. The concentrations of metals and metalloids $(\mathrm{Pb}$ total, $\mathrm{Al}$ total, $\mathrm{Fe}^{3+}$, Ni total, $\mathrm{Ag}$ total, $\mathrm{Cd}$ total, $\mathrm{Hg}$ total, As total, $\mathrm{Zn}$ total) were determined by AAS. Gas analyses were performed to determine the concentrations of free $\mathrm{CO}_{2}$, free $\mathrm{H}_{2} \mathrm{~S}$ and dissolved $\mathrm{O}_{2}$. The volumetric method was used for dissolved $\mathrm{O}_{2}$ and free $\mathrm{CO}_{2}$, while $\mathrm{H}_{2} \mathrm{~S}$ was determined by AAS.

\subsection{Petrographic-mineralogic testing of the encrustations}

Petrographic-mineralogic testing was undertaken at the laboratory of the University of Belgrade/Faculty of Mining and Geo- logy, to define the structural and textural properties of the encrustations, by means of macroscopic, optical and diffraction techniques.

\subsubsection{Macroscopic assessment of the encrustations}

The samples were tested with diluted hydrochloric acid $(\mathrm{HCl})$ in a glass, by adding $10 \mathrm{~mL}$ of the acid. The samples were observed by the naked eye and through a 20x magnifying glass.

\subsubsection{Optical assessment of the encrustations}

Three thin sections of the encrustations were prepared and viewed on a polarization microscope. A complex configuration of several software-interfaced devices was used, which included a Leica polarization microscope (model DMLSP) and Leica digital camera (model DC300).

\subsubsection{X-ray powder diffraction of the encrustations}

The encrustation samples (Fig. 4) were analyzed on an automatic powder diffractometer, Rigaku Smart Lab, under the following conditions: radiation from a copper anticathode - wavelength 


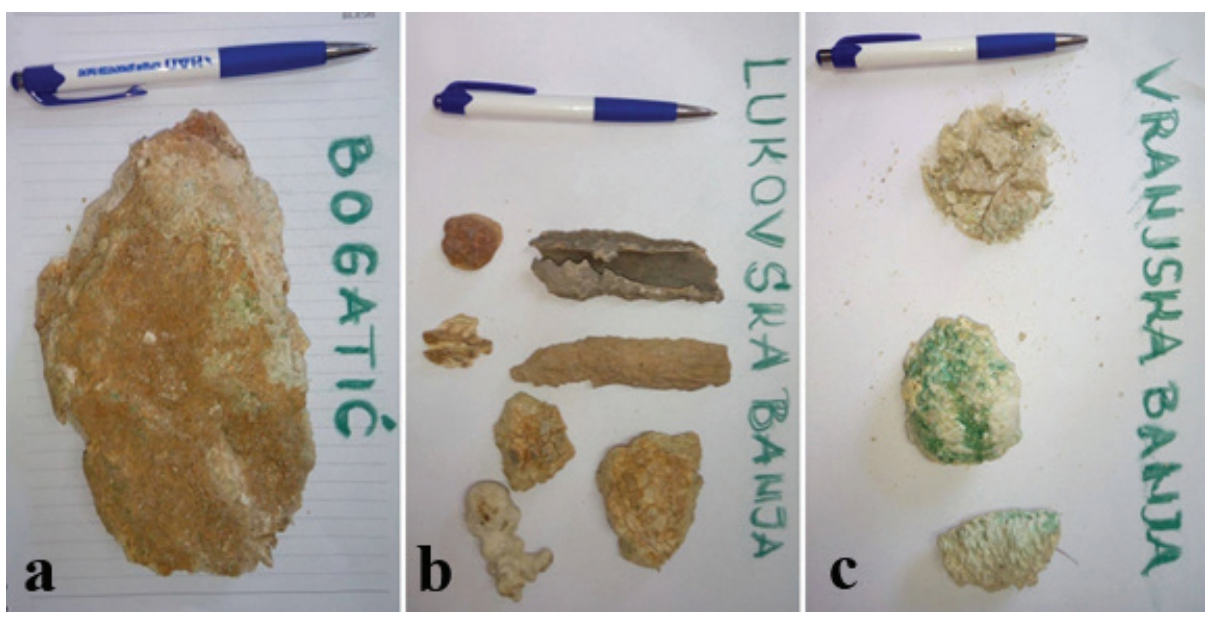

Figure 4. Samples of encrustations: a. Bogatić (sample BB-1); b. Lukovska Banja (sample LB); and c. Vranjska Banja (samples VG-2,VG-2* and VG-3) (photo: O. KRUNIĆ \&V. ŠARABA, 2017).

$\mathrm{CuK} \alpha=1.54178 \AA$, tube voltage $\mathrm{U}=40 \mathrm{kV}$, and current $\mathrm{I}=30$ $\mathrm{mA}$. The samples were analyzed in the $3-70^{\circ} 2 \Theta$ range, with a $0.01^{\circ}$ degree step and a data acquisition rate of $5.0 \% \mathrm{~min}$. The resulting diffraction maxima $2 \Theta\left({ }^{\circ}\right)$ and corresponding intensities (I) of each identified mineral were graphically represented. The crystalline phases (minerals) were identified based on intensities $\left(\mathrm{I} / \mathrm{I}_{\max }\right)$ and interplanar spacing (di), which were compared with data from the literature and ICDD PDF-2 (2016) standards.

\subsection{Hydrogeochemical modeling}

Hydrogeochemical modeling, using PHREEQC 3.4.0. (U.S. Geological Survey) and database phreeqc.dat (PARKHURST \& APPELO, 1999), and the results of chemical analyses of five mineral water samples, was undertaken to determine the saturation index (SI) of the primary minerals from the carbonate group (calcite, dolomite, aragonite), the oxide and hydroxide group (gibbsite, goethite, haematite), and the silicate group (quartz, clay minerals, micas, etc.).

\subsection{Prognostic analyses}

Prognostic analyses included mathematical calculations of the Langelier Saturation Index (SILang) and Ryznar Stability Index (SIRyz), based on the chemical parameters of the mineral waters, which were used to approximate the propensity of the mineral waters for encrustation.

\subsection{SEM analyses of phototrophic microbial mats}

Phototrophic microbial mats and microorganisms were analyzed in detail using a JEOL JSM-6610LV Scanning Electron Microscope in the Laboratory of the Faculty of Mining and Geology at the University of Belgrade. The samples were coated with gold using a BALTECSCD-005 SPUTTER coating device and recorded under high vacuum conditions, after which a high-resolution scanning electron image was obtained.

\section{RESULTS AND DISCUSSION}

The chemical composition of mineral water is a key driver of the onset and progress of encrustation, given that the process is primarily steered by dissolved salts.

The results of physical and chemical analyses showed that the mineral waters at Bogatic and Lukovska Banja are of the $\mathrm{HCO}_{3}{ }^{-}-\mathrm{Na}^{+}+\mathrm{K}^{+}$type, and at Vranjska Banja of the $\mathrm{SO}_{4}{ }^{2-}, \mathrm{HCO}_{3}{ }^{-}$ $-\mathrm{Na}^{+}+\mathrm{K}^{+}$type.
Elevated concentrations of $\mathrm{HCO}_{3}{ }^{-}$and $\mathrm{Ca}^{2+}$ ions are a mineral water parameter that causes carbonate precipitation (WOYESSA, 2012), as was found to be the case with the studied mineral water occurrences, at least with respect to the $\mathrm{HCO}_{3}{ }^{-}$ion $\left(\mathrm{HCO}_{3}{ }^{-}\right.$ : BB-1 - 361.6 mg/L; LB-4: 961.0 mg/L; LB-5: 961.0 mg/L; VG-2: $589.0 \mathrm{mg} / \mathrm{L} ; \mathrm{VG}-3: 598.0 \mathrm{mg} / \mathrm{L}$ ) (Tab. 2), given that the proportion of the $\mathrm{Ca}^{2+}$ ion is smaller than of $\mathrm{Na}^{+}+\mathrm{K}^{+}\left(\mathrm{Ca}^{2+}: \mathrm{BB}-1-33.5\right.$ $\mathrm{mg} / \mathrm{L} ; \mathrm{LB}-4$ - $41.6 \mathrm{mg} / \mathrm{L} ; \mathrm{LB}-5-83.2 \mathrm{mg} / \mathrm{L}$; VG-2 - $12.8 \mathrm{mg} / \mathrm{L}$; VG-3 - $16.0 \mathrm{mg} / \mathrm{L})$ (Tab. 2).

Waters with a $\mathrm{pH}$ of 7.5 and above and a $\mathrm{HCO}_{3}{ }^{-}$concentration of $120 \mathrm{mg} / \mathrm{L}$ and above are more likely to precipitate carbonates and form encrustations, if such waters also contain the $\mathrm{Ca}^{2+}$ ion (SCHWANKL et al., 2008), as in the case of the studied mineral waters.

The chemical composition of mineral waters is a result of the geologic framework. The geologic columns at Bogatić and Lukovska Banja include limestones, whereas those at Vranjska Banja comprise rocks of igneous/metamorphic origin (Fig. 1). The geologic framework has an indirect effect on encrustation. According to MAJKIĆ (2013), carbonate encrustations can be formed not only in limestone environments, but also at wells that tap mineral waters from other lithologic settings, with carbonate concentrations greater than several mass percent, as in the case of the wells at Vranjska Banja, where all the occurrences exhibited encrustations of carbonate origin. VAN BEEK et al. (2010), report similar findings, pointing out the dominant presence of carbonate encrustations in limestone environments. Encrustations of various origins, including carbonate, can be found in metamorphic settings and those with intercalations of igneous rocks.

All the tested occurrences belong to the group of hot mineral waters, with a temperature range of $62-93.9^{\circ} \mathrm{C}$ and a $\mathrm{pH}$ range of $6.6-8.0$ : mildly acidic (well LB-5) to mildly alkaline (wells BB-1, LB-4, VG-2 and VG-3) mineral waters. According to JONES \& RENAUT (2010), high temperatures and elevated $\mathrm{pH}$ of mineral waters are conducive to, inter alia, carbonate encrustation.

WOYESSA (2012) and DEMIR et al. (2014) also point out that carbonate encrustations on mineral water wells, especially where mineral waters are hot $\left(>60^{\circ} \mathrm{C}\right)$. RICHARDS (2016) discusses the importance of temperature from the carbonate encrustations perspective and shows that waters of moderate hardness and alkalinity tend to be devoid of carbonate encrustations at 
lower temperatures. A temperature increase leads to encrustation, if all other conditions remain constant.

The following types of encrustations are mostly observed in mineral waters with elevated temperature: (i) carbonates, such as calcium and strontium carbonates, (ii) silicates, (iii) heavy metal sulfides, and (iv) various types of chloride compounds (JURÁNEK et al., 1987; ARNÓRSSON, 1989; GILL, 1998; POTAPOV et al., 2001; GALLUP, 2002; DEMIR et al., 2014). In addition, waters of high temperature are saturated with silicon dioxide and nearly saturated with calcite, calcium sulfate, calcium fluoride, magnesium silicates, aluminum, iron, and metal sulfides (ÖLÇENOĞLU, 1986; GUNNLAUGSSON \& EINARSSON, 1989; KRISTMANNSDÓTTIR, 1989; HONEGGER et al., 1989; PÁTZAY et al., 2003; DEMIR et al., 2014).

WOYESSA (2012) reports data on carbonate encrustation from mineral waters with $\mathrm{pH}$ levels lower than 8.3 , which is the case in the present study (pH: BB-1-6.9; LB-4 - 7.5; LB-5 - 6.6; VG-2 - 7.9; VG-3 - 8.0) (Tab. 2), and APPELO \& POSTMA (2004) state that carbonate encrustations are dominant at $\mathrm{pH}<8.3$.

Conductivity, a property of mineral water determined in situ, which depends on the concentration of dissolved salts, measured higher values in Lukovska Banja and Vranjska Banja (wells: LB-4
- $1513 \mu \mathrm{S} / \mathrm{cm}$; LB-5 - $1588 \mu \mathrm{S} / \mathrm{cm}$; VG-2 - $1584 \mu \mathrm{S} / \mathrm{cm}$; VG-3 $1707 \mu \mathrm{S} / \mathrm{cm})$. This was an indicator of a higher TDS level compared to the mineral water at Bogatic (well BB-1 - $800 \mu \mathrm{S} / \mathrm{cm}$ ). Following accurate determination of TDS, the occurrences in Lukovska Banja and Vranjska Banja were classified as mineral waters where total dissolved salts were greater than $1 \mathrm{~g} / \mathrm{L}$ (wells: LB-4 - 1267 mg/L; LB-5 - 1058 mg/L; VG-2 - 1213 mg/L; VG-3 - $1145 \mathrm{mg} / \mathrm{L}$ ). The occurrence at Bogatić belongs to the group of mineral waters with concentrations of dissolved salts less than $1 \mathrm{~g} / \mathrm{L}$ (well BB-1 - 600 mg/L) (Tab. 2).

TDS directly affects encrustation; the higher the TDS level, the more probable the creation of encrustations (PAPIĆ, 1999).

Gas analyses included carbon dioxide $\left(\mathrm{CO}_{2}\right)$, oxygen $\left(\mathrm{O}_{2}\right)$ and hydrogen sulfide $\left(\mathrm{H}_{2} \mathrm{~S}\right)$. The concentration of $\mathrm{CO}_{2}$ was significant from a carbonate encrustations perspective. According to HOUBEN (2001) and DEED \& PREENE (2015), carbonate encrustations, contrary to iron encrustations, occur when the partial pressure of $\mathrm{CO}_{2}$ is lower than the atmospheric pressure, especially under high water temperature conditions as in the study cases. $\mathrm{CO}_{2}$ is released from the water and disturbs the carbonate equilibrium of the solution, leading to carbonate encrustation.

Table 2. Results of physical and chemical analyses of the studied occurrences of mineral water (ŠARABA et al., 2017).

\begin{tabular}{|c|c|c|c|c|c|}
\hline \multirow{2}{*}{ Parameter } & \multirow{2}{*}{$\begin{array}{c}\text { Bogatić } \\
\text { BB-1 }\end{array}$} & \multicolumn{2}{|c|}{ Lukovska Banja } & \multicolumn{2}{|c|}{ Vranjska Banja } \\
\hline & & LB-4 & LB-5 & VG-2 & VG-3 \\
\hline $\mathrm{T}\left({ }^{\circ} \mathrm{C}\right)$ & 65.9 & 68.1 & 62.0 & 93.9 & 91.2 \\
\hline TDS (mg/l) & 600 & 1267 & 1058 & 1213 & 1145 \\
\hline $\mathrm{pH}$ & 6.9 & 7.5 & 6.6 & 7.9 & 8.0 \\
\hline $\mathrm{T}(\mathrm{NTU})$ & / & / & 14.9 & 0.6 & 0.8 \\
\hline $\mathrm{KMnO}_{4}$ demand (mg/L) & 6.9 & 2.2 & 3.2 & 5.5 & 4.2 \\
\hline Color (PT-Co scale) & / & / & 25 & $<5$ & $<5$ \\
\hline $\mathrm{EC}(\mu \mathrm{S} / \mathrm{cm})$ & 800 & 1513 & 1588 & 1584 & 1707 \\
\hline \multicolumn{6}{|c|}{ MACROCOMPONENTS (mg/L) } \\
\hline $\mathrm{Na}^{+}$ & 144.0 & 309.6 & 166 & 358.0 & 346.4 \\
\hline $\mathrm{K}^{+}$ & 13.0 & 23.6 & 18.6 & 19.4 & 18.4 \\
\hline $\mathrm{Ca}^{2+}$ & 33.5 & 41.6 & 83.2 & 12.8 & 16.0 \\
\hline $\mathrm{Mg}^{2+}$ & 6.6 & 17.1 & 32 & $<1.0$ & $<1.0$ \\
\hline $\mathrm{HCO}_{3}^{-}$ & 361.6 & 961.0 & 961.0 & 589.0 & 598.0 \\
\hline $\mathrm{SO}_{4}{ }^{2-}$ & 7.5 & 91.3 & 50.3 & 548.7 & 487.0 \\
\hline $\mathrm{Cl}^{-}$ & 103.4 & 82.0 & 46.0 & 64.0 & 60.0 \\
\hline \multicolumn{6}{|c|}{ MICROCOMPONENTS (mg/L) } \\
\hline $\mathrm{Pb}$ & $<0.003$ & / & 0.04 & $<0.01$ & $<0.01$ \\
\hline $\mathrm{Fe}^{3+}$ & 0.17 & 0.23 & 0.07 & 0.20 & $<0.10$ \\
\hline $\mathrm{Al}$ & $<0.04$ & $<0.04$ & $<0.04$ & 5.04 & 5.04 \\
\hline $\mathrm{Ni}$ & l & l & 0.11 & $<0.01$ & $<0.01$ \\
\hline $\mathrm{Ag}$ & / & I & $<0.013$ & / & I \\
\hline $\mathrm{Cd}$ & l & / & / & $<0.02$ & $<0.02$ \\
\hline $\mathrm{Hg}$ & / & / & / & $<0.001$ & $<0.001$ \\
\hline As & 0.002 & / & 0.689 & $<0.01$ & $<0.01$ \\
\hline $\mathrm{Zn}$ & 0.002 & / & $<0.014$ & $<0.02$ & $<0.02$ \\
\hline $\mathrm{NO}_{3}^{-}$ & 0.3 & 0.7 & 0.5 & 2.3 & 5.3 \\
\hline $\mathrm{NO}_{2}^{-}$ & 0.002 & 0.005 & $<0.005$ & $<0.02$ & $<0.02$ \\
\hline $\mathrm{NH}_{4}^{+}$ & 1.80 & 1.05 & 0.75 & 0.31 & 0.32 \\
\hline $\mathrm{SiO}_{2}$ & 64 & 50 & 50 & 90 & 90 \\
\hline \multicolumn{6}{|c|}{ GASES (mg/L) } \\
\hline Free $\mathrm{CO}_{2}$ & 50.5 & 140.0 & 150.0 & 184.6 & 194.2 \\
\hline Dissolved $\mathrm{O}_{2}$ & 0.5 & I & / & 4.5 & 3.7 \\
\hline Free $\mathrm{H}_{2} \mathrm{~S}$ & 2.5 & I & $<0.06$ & 0.008 & 0.006 \\
\hline
\end{tabular}

Legend: Forward slash $(/)=$ not analyzed. 
$\mathrm{CO}_{2}$ release from the water increases the $\mathrm{pH}$ level, which contributes to carbonate precipitation (APPELO \& POSTMA, 2004).

In addition, gas solubility decreases with increasing water temperature, which leads to the release of $\mathrm{CO}_{2}$. The solubility of carbonates in water depends on the amount of dissolved $\mathrm{CO}_{2}$. As this amount decreases, so does the solubility of carbonate minerals, resulting in a higher rate of carbonate encrustation of the well. This reaction is rapid, such that carbonate encrustations are formed almost instantly (APPELO \& POSTMA, 2004; HOUBEN \& TRESKATIS, 2007; BROWN, 2013).

In such a setting, carbonate encrustation can be expressed by a reverse reaction (1), where there is an equilibrium between calcium hydrogencarbonates, calcium and hydrogencarbonate ions, solid calcium carbonate, and carbon dioxide in the mineral water solution (APPELO \& POSTMA, 2004):

$\mathrm{Ca}\left(\mathrm{HCO}_{3}\right)_{2} \leftrightarrow \mathrm{Ca}^{2+}+2 \mathrm{HCO}_{3}^{-} \leftrightarrow \mathrm{CaCO}_{3 \downarrow}+\mathrm{CO}_{2}+\mathrm{H}_{2} \mathrm{O},(1)$

The highest concentrations of this gas were recorded at Vranjska Banja (well VG-2 - 184.6 mg/L free $\mathrm{CO}_{2}$; well VG-3 - 194.2 $\mathrm{mg} / \mathrm{L}$ free $\mathrm{CO}_{2}$ ) and Lukovska Banja (wellLB-4 - $140.0 \mathrm{mg} / \mathrm{L}$ free $\mathrm{CO}_{2}$; wellLB-5 - $150.0 \mathrm{mg} / \mathrm{L}$ free $\mathrm{CO}_{2}$ ). Those at Bogatić were lower (well BB-1 - 50.5 mg/L free $\mathrm{CO}_{2}$ ) (Tab. 2).

The chemical compositions of the examined occurrences were illustrated in hydrochemical diagrams, which clearly indicate the hydrochemical types of mineral water at each location.
Figure 5 shows the basic ionic compositions, which are indirectly indicative of the TDS levels. It is apparent that the $\mathrm{HCO}_{3}{ }^{-}$ and $\mathrm{Na}^{+}+\mathrm{K}^{+}$ions were dominant in the mineral waters at Bogatic and Lukovska Banja, while at Vranjska Banja there were also elevated concentrations of the $\mathrm{SO}_{4}{ }^{2-}$ ion. Figure 5 also shows that at Bogatic the highest proportion is of the $\mathrm{HCO}_{3}$-ion, followed by the $\mathrm{Cl}^{-}$ion. The waters at Lukovska Banja and Vranjska Banja measured the lowest $\mathrm{Cl}^{-}$ion concentrations. With regard to all the mineral water occurrences, the decreasing order was $\mathrm{Na}^{+}+\mathrm{K}^{+}$, $\mathrm{Ca}^{2+}$ and $\mathrm{Mg}^{2+}$. It is apparent that the mineral water from Bogatic measured the lowest concentration of dissolved salts and that TDS was less than $1 \mathrm{~g} / \mathrm{L}$, compared to the other occurrences where TDS was greater than $1 \mathrm{~g} / \mathrm{L}$.

Figure 6 is a hydrochemical $\mathrm{Cl}^{-}-\mathrm{SO}_{4}{ }^{2-}-\mathrm{HCO}_{3}{ }^{-}$ternary graph, which shows that all the tested mineral water samples were in the high bicarbonate ion concentration range and that the mineral waters could be classified as peripheral waters that may have mixed with cold groundwater. The mineral water at well BB-1 (Bogatić) was near the $\mathrm{Cl}^{-}$range but still in the $\mathrm{HCO}_{3}{ }^{-}$range, which is indicative of $\mathrm{Cl}^{-}$being the second prevalent ion, after bicarbonate. The position on the graph also suggests very low concentrations of the $\mathrm{SO}_{4}{ }^{2-}$ ion. Closely positioned mineral waters from wells LB-4 and LB-5 (Lukovska Banja), and wells VG-2 and VG-3 (Vranjska Banja), are a result of the same geologic setting from which the mineral waters are extracted. This has led to similar concentrations of the $\mathrm{HCO}_{3}^{-}, \mathrm{SO}_{4}{ }^{2-}$ and $\mathrm{Cl}^{-}$anions. In the case of the mineral waters from wells LB-4 and LB-5 (Lukovska
BB-1

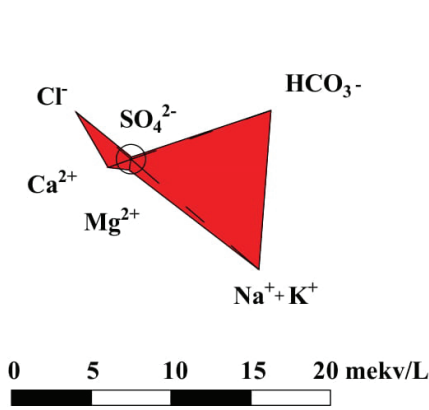

VG-2
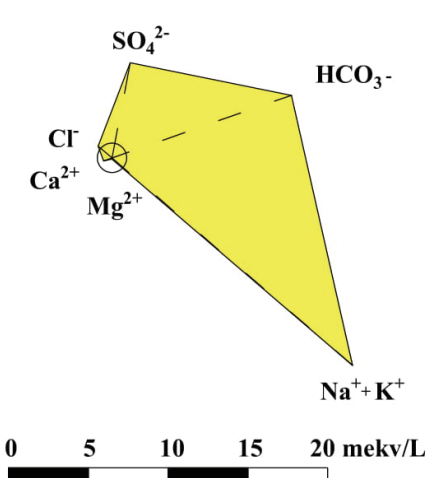

LB-4
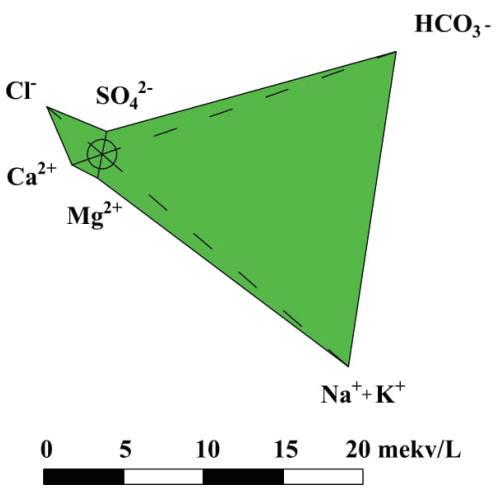

VG-3
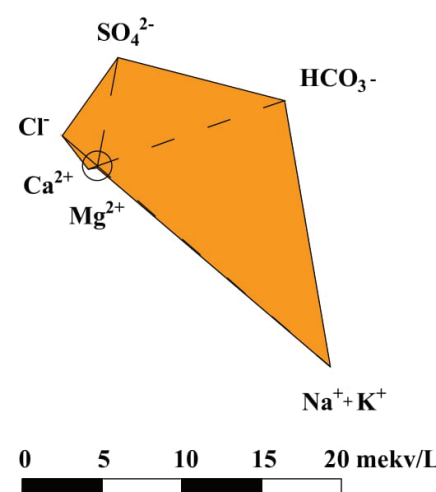

Figure 5. Diagram of radial coordinates of the tested mineral waters.

Legend: BB-1 - well in Bogatić; LB-4, LB-5 - wells in Lukovska Banja;VG-2, VG-3 - wells in Vranjska Banja. 


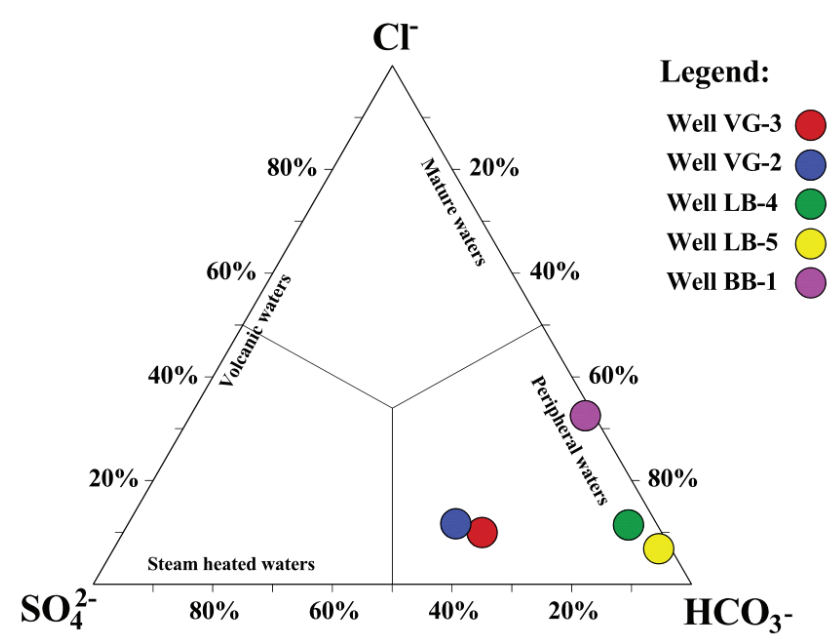

Figure 6. Ternary $\mathrm{Cl}^{-}-\mathrm{SO}_{4}{ }^{2-}-\mathrm{HCO}_{3}{ }^{-}$graph of the tested mineral waters.

Banja), the points are close to the corner of $\mathrm{HCO}_{3}{ }^{-}$, such that these waters have high bicarbonate concentrations. The mineral waters from wells VG-2 and VG-3 are near the steam heated waters, but still in the peripheral range. In such cases bicarbonate and sulfate ions are predominant.

According to DOLGORJAV (2009), closely positioned mineral waters on the $\mathrm{Cl}^{-}-\mathrm{SO}_{4}{ }^{2-}-\mathrm{HCO}_{3}{ }^{-}$graph (Fig. 6), such as those from wells VG-2 and VG-3 (Vranjska Banja), originate from high-temperature systems and can be associated with deep geologic structures.

Encrustation samples (Fig. 4) were tested by various methods, in order to conduct a detailed analysis.

Macroscopic assessment of the samples (Fig. 4) revealed their colour, structure and texture: grain size, type and shape; lamination; and traces of damage/abrasion. Optical assessment and the increased contrast offered by this type of microscopy, provided a sample image with a high level of sensitivity for quantitative and qualitative determinations (Fig. 4). The X-ray powder diffraction technique was used to determine the phase composition of the samples (Fig. 4), or, in other words, to conduct qualitative analyses. The advantage compared to other methods is that it is possible to determine which mineral is present in the samples even where the total chemical composition has been determined.

Macroscopic tests of all samples (wells BB-1, LB-4, LB-5, VG-2, VG-3) with diluted hydrochloric acid ( $\mathrm{HCl})$ resulted in strong reactions, which indicated a significant presence of calcite $\left(\mathrm{CaCO}_{3}\right)$. The colour of the post-test solutions was dark, a potential indicator of iron oxides and hydroxides in the samples.

GUNNLAUGSSON et al. (2014) report data on encrustations of carbonate origin (calcite and aragonite) in hot mineral water wells, which are exceptionally white in color and devoid of impurities. This was not the case in the present study.

The carbonate encrustations, along with iron and manganese oxides and hydroxides, were of the standard type found in and around wells, as corroborated by the examples of select occurrences of mineral waters, where as carbonate encrustations in combination with sulfates, sulfides and aluminum hydroxides are much less frequent (HOUBEN, 2000; HOUBEN, 2001).

Macroscopic assessment of the samples from wells BB-1 (Bogatić), LB-4 and LB-5 (Lukovska Banja) revealed a micro/ coarse crystalline structure and a relatively well-preserved texture. Multiphasic development was noted, which lent a certain laminarity to the samples. The colours of the laminae varied, from brown/ochre at well BB-1 (Bogatić) to light brown, dark brown or dark gray at wells LB-4 and LB-5 (Lukovska Banja). The samples also exhibited thin and irregular lamination. Structurally, there were thick micritic and highly porous laminae or coarse crystalline interlayers.

The two alternating types of laminae could be a result of calcite precipitation from warm and cold water, and the growth of Cyanobacteria driven by seasonal changes (TIŠLJAR, 2001).

PEDLEY (1992), PERRY (1999) and RIDING (2000) point out frequent examples of the influence of phototrophic microbial mats on the formation of sediment textures, such as laminations and stromatolites.

The samples were relatively hard and could not be crushed between fingers when dry.

Optical assessment corroborated a distinct laminar texture of the samples from wells BB-1 (Bogatić), LB-4 and LB-5 (Lukovska Banja), where the laminae were very thin, from 0.025 to $1 \mathrm{~mm}$. Their colour differed. All the laminae, regardless of thickness, ware more or less wavy, at times leading to a deformed texture-microconvolutions.

Optical assessment of the sample from well BB-1 (Bogatić) led to the conclusion that the predominant component was calcite. It was present in crystalline grains of various sizes - from microns (greater than 10 microns) to parts of a millimetre. The sizes of the largest monocrystals or monocrystal aggregates were up to $0.5 \mathrm{~mm}$. The crystalline calcite grains were clear and birefractive. Such calcite was associated with light, predominantly calcite laminae (Fig. 7a).

de ZWART (2007) reports similar calcite crystal sizes in carbonate encrustations around wells, indicative of irregular calcite crystal shapes in the size range of $3-5 \mu \mathrm{m}$.

Dark, semi-transparent grains were the second largest constituent of samples from well BB-1 (Bogatić). These grains were aggregates of microcrystalline calcite, heavily stained by iron hydroxides (probably amorphous). They originated from thin, dark brown laminae (Fig. 7a).

The non-carbonate part of a sample from well BB-1 (Bogatić) was a terrigenous component of pelitic size (clay minerals), intimately mixed with microcrystalline calcite, including a very small quantity of quartz grains and phyllosilicate flakes (sericite/ fine flaky muscovite) of silt size. Organic matter was finely dispersed in the sample. According to optical indicators, its concentration was less than $2 \%$. The sample from well BB-1 (Bogatić) was identified as a wavy laminated calcite deposit.

$\mathrm{X}$-ray powder diffraction on a sample from well BB-1 (Bogatić) corroborated that the primary constituent was calcite, accompanied by a much smaller quantity of quartz (Fig. 8a).

Optical assessment of samples from wells LB-4 and LB-5 (Lukovska Banja) led to the conclusion that the predominant constituent was crystalline calcite. There were also aggregates of microcrystalline calcite, intimately mixed with iron hydroxides. The sample contained distinct grains with radially developed carbonate (Fig. 7b). This carbonate - aragonite generally crystallizes in high-temperature waters. At Lukovska Banja (wells LB-4 and LB-5), measured water temperatures ranged from $62^{\circ} \mathrm{C}$ to $68^{\circ} \mathrm{C}$ (Tab. 2).

In addition, aragonite aggregate needles can host microorganisms which, inter alia, cause aragonite precipitation (GUO \& RIDING, 1992). As already mentioned, microbial growth in phototrophic mats was noted in the studied occurrences. PLUMMER et al. (1978), BUHMANN \& DREYBRODT (1987), CHAFETZ 

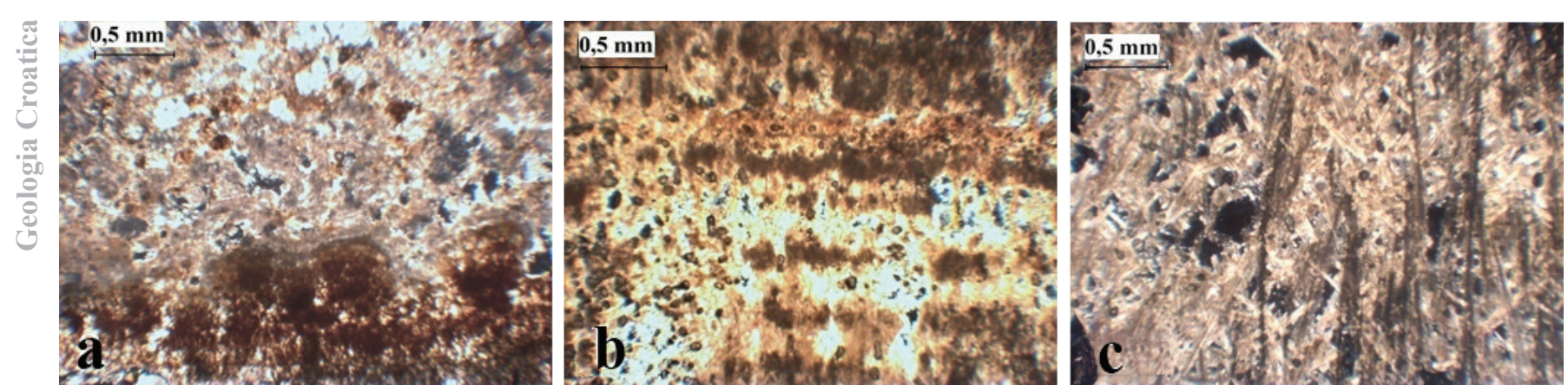

Figure 7. Microscopic view of the samples collected from: a. well BB-1 (Bogatić), b. wells LB-4 and LB-5 (Lukovska Banja), c. well VG-2 (Vranjska Banja). Legend: a. Fine crystalline calcite base. Dark lamellae comprised of grains, aggregates of micritic calcite stained by Fe hydroxides; b. Fine crystalline calcite base. Dark grains/lamellae are micritic calcite stained by Fe hydroxides; c. Fine crystalline calcite base, interspersed with aragonite filaments. Darker grains are aggregates of calcite and aragonite stained by Fe hydroxides.

(1994) and FLÜGEL (2004) state that carbonates are the most frequent types of encrustations and those microorganisms are mediators of their creation, while FLÜGEL (2013) claims that carbonates are very often formed by freshwater microorganisms. The studied occurrences of mineral water belong to this category.

Samples from wells LB-4 and LB-5 (Lukovska Banja) also included terrigenous components (fine-grained sand fraction), but their concentrations were low. It is possible that fine quartz grains were a result of contamination during sampling or that they became attached during carbonate incrustation. Based on optical indicators, samples from wells LB-4 and LB-5 (Lukovska Banja) were identified as a laminar calcite deposit.

The predominant calcite mineral in samples from wells LB-4 and LB-5 (Lukovska Banja) was corroborated by X-ray powder diffraction. Aragonite was next, but its concentration was much lower (Fig. 8b).

Macroscopic assessment of samples VG-2, VG-2*and VG-3 from wells VG-2 and VG-3 (Vranjska Banja) led to the conclusion that their texture was disturbed during sampling. The samples were loose, comprised of particles, grains and fragments of sub-millimetre to centimetre size. The coarse, centimetre fragments were in shades of light gray and light brown. Based on sample VG-2* from well VG-2 (Vranjska Banja), it was assumed that the texture of the other two samples (VG-2 and VG-3) from wells VG-2 and VG-3 (Vranjska Banja) was the same. They exhibited irregular lamination, with thin micritic to semi-crystalline laminae and laminae comprised of aggregates of clustered aragonite needles (Fig. 7c).
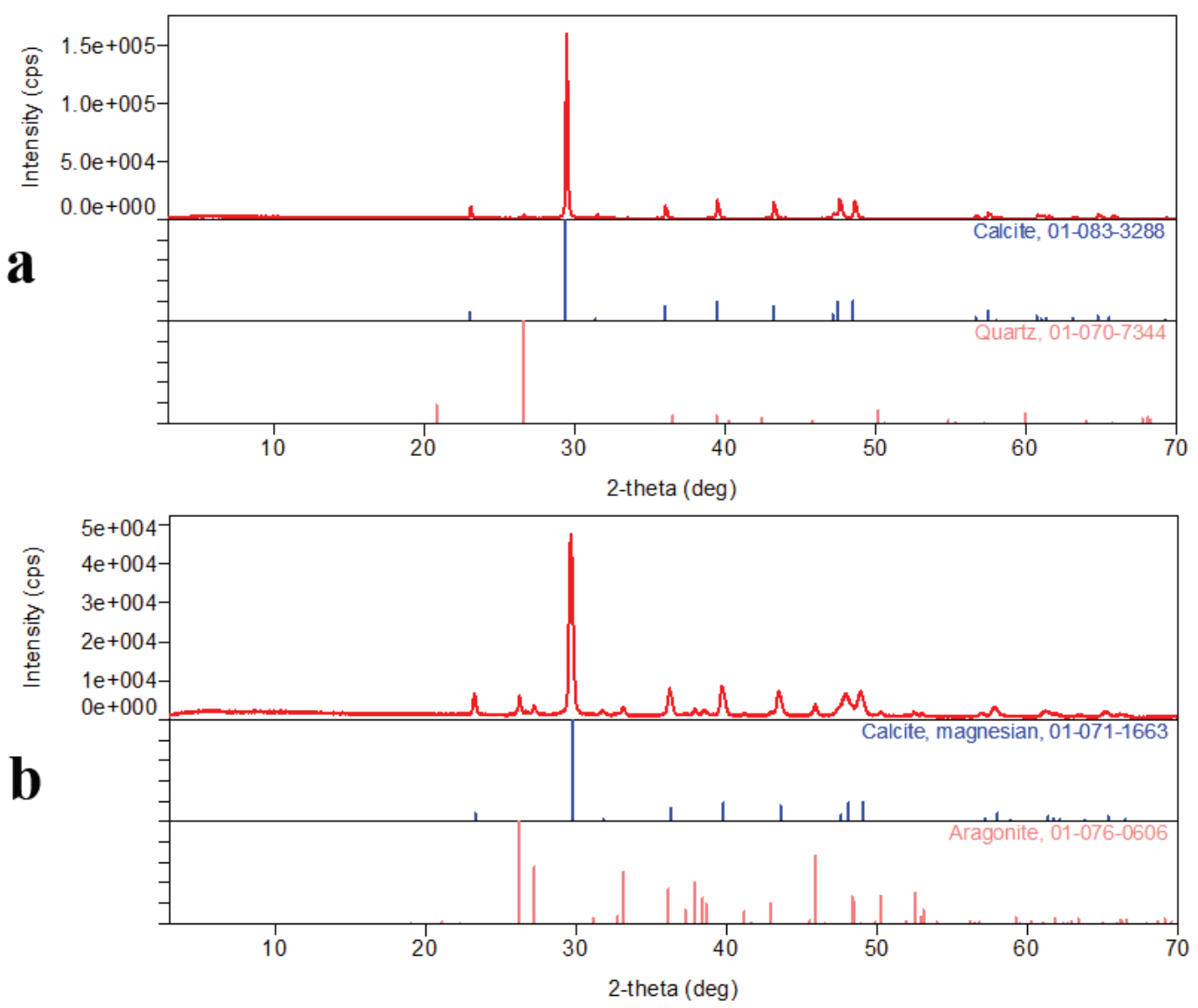

Figure 8. Results of X-ray powder diffraction of the samples: a. BB-1 from well BB-1 (Bogatić); b. LB from wells LB-4 and LB-5 (Lukovska Banja). 

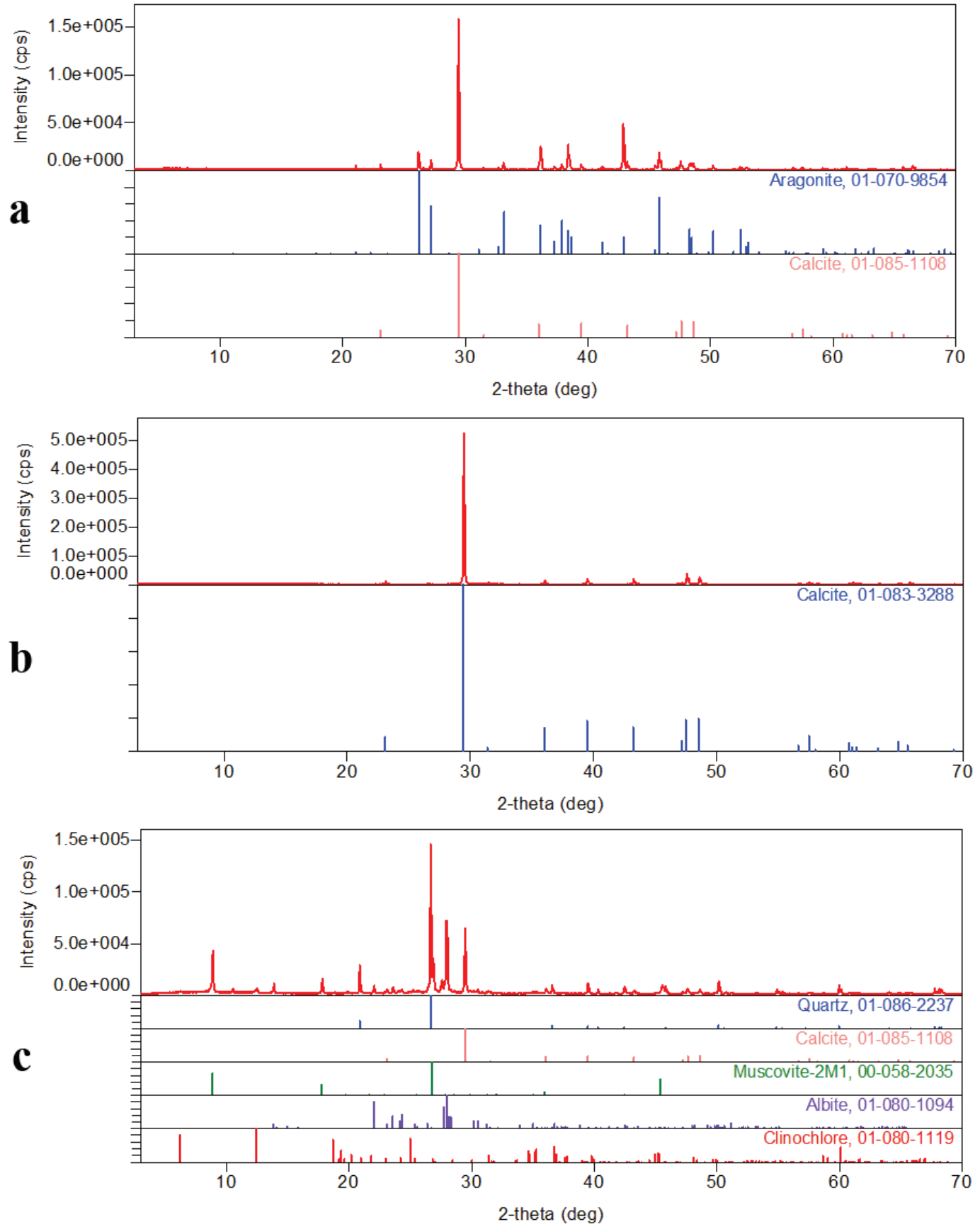

Figure 9. Results of X-ray powder diffraction of the samples: a. VG-2 from well VG-2 (Vranjska Banja); b.VG-2* from well VG-2 (Vranjska Banja); c. VG-3 from well VG-3 (Vranjska Banja).

Sample VG-2 from well VG-2 (Vranjska Banja) was tested by optical microscopy and samples VG-2, VG-2* and VG-3 from wells VG-2 and VG-3 (Vranjska Banja) were analyzed in detail by X-ray powder diffraction.

Optical assessment of sample VG-2 from well VG-2 (Vranjska Banja) led to the conclusion that the sample comprised calcite and aragonite aggregate rods and filaments. Breakage of the filaments was not readily visible. The structure was micro to coarse crystalline. The coarse calcite monocrystals were highly translucent. The other parts of the sample were difficult to determine optically but they included clay minerals and $\mathrm{Fe}$ oxides and hydroxides, which had stained the sample in shades of brown (Fig. 7c). Based on optical indicators, sample VG-2 from well VG-2 (Vranjska Banja) was identified as a calcite-aragonite deposit.
X-ray powder diffraction revealed that in sample VG-2 from well VG-2 (Vranjska Banja) the prevalent mineral was calcite, followed by aragonite. There were no other mineral phases (Fig. 9a). Sample VG-2* from well VG-2 (Vranjska Banja) contained only calcite (Fig. 9b). The primary constituent of sample VG-3 from well VG-3 (Vranjska Banja) was quartz, followed by calcite and a mineral from the mica group (muscovite). Minerals from the plagioclase and chlorite groups were less represented (Fig. 9c).

The results of petrographic-mineralic testing showed that the mineral and chemical compositions of the encrustations were practically the same. Their common features included the predominance of calcium carbonate, a thickness of only several centimetres, and a high porosity of the samples.The texture was characterized by alternating horizontal or wavy carbonate laminae, comprised of micrites in shades of brown, stained by iron 
oxides and hydroxides or organic substances, and those comprised of radial or medium-to-coarse crystalline calcite and aragonite.

de ZWART (2007) describes encrustations around wells and points out the carbonate composition and iron oxides in the mineral matrix, along with organic components originating from the aquifer. Sedimentation is governed by changes in hydrochemical and flow conditions, with other potential additional factors.

Apart from calcite, the precipitation of minerals such as chlorite, mica, etc. is also possible (de ZWART, 2007). This is true of the mineral water in Vranjska Banja, where quartz, albite, muscovite and clinochlore were detected.

DEMIR et al. (2014) also provide data on carbonate encrustations in hot mineral water wells and on water pipes, represented by calcite and aragonite, along with lead sulfide. Given that aragonite is not thermodynamically stable under ambient conditions, but stable at elevated temperatures and pressures, there was a gradual transition from calcite to aragonite at increasing depths in the well, as the temperature and pressure gradually increased with depth (DEMIR et al., 2014). MITIĆ et al. (2014) report comparable findings, indicative of the carbonate composition of encrustations in $\mathrm{HCO}_{3}{ }^{-}-\mathrm{Na}^{+}+\mathrm{K}^{+}$mineral waters, at a temperature of $75^{\circ} \mathrm{C}$, primarily composed of aragonite, along with calcite and vaterite, as well as small amounts of anhydrite, in a $1232 \mathrm{~m}$-deep well. Similar temperatures characterized the selected occurrences of mineral waters in Serbia, as well as an identical basic ionic composition. The presence of aragonite, detected in Lukovska Banja (wells LB-4 and LB-5) and Vranjska Banja (well VG-2), keeping in mind the reports by DEMIR et al. (2014) and MITIĆ et al. (2014), might be indicative of a temperature gradient in the zone of discharge and at the wellheads, as well as that calcite, dominant in the composition of the encrustations, could be a result of aragonite inversion, due to decreasing temperatures and pressures in discharge zones and on wellheads, relative to the increase in these parameters with depth. In addition, PERDIKOURI et al. (2011) claim that the creation of calcite need not be a result of aragonite inversion.

Such encrustations are created through precipitation from mineral waters and can be interpreted as deposition of terrestrial freshwater carbonates (calc tufa, travertine, etc.) (GUO \& RIDING, 1992; CHAFETZ \& FOLK, 1984; PERDIKOURI et al., 2011).

DRISCOLL (1986) and HOUBEN \& TRESKATIS (2007) state that the main types of encrustations are chemical compounds generated through the precipitation of calcium and magnesium carbonates and sulfates, and iron and manganese compounds - primarily hydroxides and oxides, but that there are also encrustations created by mechanical or chemical action of various microbial species, which are the most frequently encountered encrustations in Serbia (ŠARABA et al., 2017).

Carbonate encrustations favour other conditions as well, such as (SCHWANKL et al., 2008): (i) groundwater extraction leading to changes in pressure at the point of entry into the well, which promotes carbonate encrustation, (ii) mixing of waters from different geological formations, increasing the probability of carbonate encrustation given that the studied mineral water occurrences are characterized by a complex geological framework (Fig. 1), (iii) evaporation of drops of mineral water, which increases the concentration of dissolved salts in the groundwater, thus contributing to precipitation.

Based on the mechanical characteristics of the macroscopically assessed encrustations, they can be classified keeping in mind GAVRILKO \& ALEKSEEV (1985), who identified four types, disregarding the mineral composition of the encrustations: (i) very hard conglomeratic type, (ii) loosely stratified type, represented by cemented fine-grained material, (iii) unconsolidated porous type, characterized by high porosity of the deposited mass, and (iv) soft, pasty or jelly like deposits that contain a significant amount of organic matter. In this regard, the encrustations from Bogatic and Lukovska Banja belong to the first type and those from Vranjska Banja to the third type of encrustations.

In addition, very hard carbonate encrustations are generally associated with rhombohedral calcite, whereas soft and soluble carbonate encrustations are mostly built up of orthorhombic calcite and are easier to remove from different surfaces (STOJILJKOVIĆ et al., 2015).

The hydrogeochemical modeling program PHREEQC 3.4.0. (U.S. Geological Survey) and database phreeqc.dat (PARKHURST \& APPELO, 1999) were used to process the set of hydrochemical data, shown in Table 2, and to calculate the saturation index (SI) of all minerals that can hypothetically be formed from the mineral water of a given chemical composition. The focus was on the primary minerals of the carbonate group (calcite, dolomite and aragonite), the oxide and hydroxide group (gibbsite, goethite and haematite), and the silicate group (quartz, clay minerals, micas, etc.), as the most probable constituents of the studied encrustations. Only positive values of the saturation index (SI $>0)$ were interpreted, given that they suggested supersaturation of the water with a given mineral and, consequently, the possibility of its precipitation (APPELO \& POSTMA, 1994). The results of modeling are shown in Table 3.

Given that the presence or absence of a certain mineral in encrustations depends, inter alia, on the precipitation rate under given conditions (i.e. $\mathrm{SI}>0$ does not necessarily mean that the mineral is in fact present in the encrustations), the results of hydrogeochemical modeling of SI were interpreted in accordance with those of the macroscopic and optical assessments and X-ray powder diffraction.

The saturation index of the sample of mineral water from Bogatić (well BB-1) was indicative of only a slight calcite supersaturation, which suggested the possibility of small carbonate deposits through encrustation. This was corroborated by mineralogic analyses of the sample from that location. Mild supersaturation of the mineral water with quartz $(\mathrm{SI}=0.15)$ was insufficient to create silicate encrustations (BROWN, 2013). The other positive SI values were associated with iron oxides and hydroxides, as well as muscovite and kaolinite, which comprised the noncarbonate part of the examined encrustations. A comparison of the hydrogeochemical model of the mineral water sample from well BB-1 with the results of optical and X-ray assessments of the encrustations from well BB-1 revealed that all of the minerals identified in the encrustations were indeed precipitated from the mineral water, with the exception of quartz grains, which were likely a result of contamination during sampling.

Hydrogeochemical modeling of the mineral water samples from Lukovska Banja (wells LB-4 and LB-5) indicated possible precipitation of calcite and aragonite, as well as iron oxides and hydroxides. The presence of these minerals was corroborated by mineralogic and X-ray analyses of the encrustation samples. The model also suggested the possibility of precipitation of magnesium and potassium silicates, as well as kaolinite and dolomite, but they were not detected in the sample. Quartz was virtually in a state of chemical equilibrium with water (positive SI, but close to zero), so the assumption was that its presence in the encrustations was a result of contamination during sampling. 
Table 3. Saturation indices (SI) of the primary minerals from the carbonate group (calcite, dolomite and aragonite), the oxide and hydroxide group (gibbsite, goethite and haematite), and the silicate group (quartz, clay minerals, micas, etc.).

\begin{tabular}{|c|c|c|c|}
\hline Locality/Well & Mineral phase & $\mathrm{SI}$ & Formula \\
\hline \multirow{6}{*}{$\begin{array}{c}\text { Bogatić } \\
\text { (BB-1) }\end{array}$} & Calcite & 0.08 & $\mathrm{CaCO}_{3}$ \\
\hline & Goethite & 7.03 & $\mathrm{FeOOH}$ \\
\hline & Haematite & 16.24 & $\mathrm{Fe}_{2} \mathrm{O}_{3}$ \\
\hline & K-mica & 3.67 & $\mathrm{KAl}_{3} \mathrm{Si}_{3} \mathrm{O}_{10}(\mathrm{OH})_{2}$ \\
\hline & Kaolinite & 0.86 & $\mathrm{Al}_{2} \mathrm{Si}_{2} \mathrm{O}_{5}(\mathrm{OH})_{4}$ \\
\hline & Quartz & 0.15 & $\mathrm{SiO}_{2}$ \\
\hline \multirow{9}{*}{$\begin{array}{l}\text { Lukovska Banja } \\
\text { (LB-4) }\end{array}$} & Aragonite & 0.93 & $\mathrm{CaCO}_{3}$ \\
\hline & Calcite & 1.04 & $\mathrm{CaCO}_{3}$ \\
\hline & Chlorite(14A) & 2.92 & $\mathrm{Mg}_{5} \mathrm{Al}_{2} \mathrm{Si}_{3} \mathrm{O}_{10}(\mathrm{OH})_{8}$ \\
\hline & Chrysotile & 0.05 & $\mathrm{Mg}_{3} \mathrm{Si}_{2} \mathrm{O}_{5}(\mathrm{OH})_{4}$ \\
\hline & Dolomite & 2.19 & $\mathrm{CaMg}\left(\mathrm{CO}_{3}\right)_{2}$ \\
\hline & Goethite & 7.14 & $\mathrm{FeOOH}$ \\
\hline & Haematite & 16.46 & $\mathrm{Fe}_{2} \mathrm{O}_{3}$ \\
\hline & K-mica & 2.09 & $\mathrm{KAl}_{3} \mathrm{Si}_{3} \mathrm{O}_{10}(\mathrm{OH})_{2}$ \\
\hline & Quartz & 0.01 & $\mathrm{SiO}_{2}$ \\
\hline \multirow{8}{*}{$\begin{array}{l}\text { Lukovska Banja } \\
\qquad \text { (LB-5) }\end{array}$} & Aragonite & 0.31 & $\mathrm{CaCO}_{3}$ \\
\hline & Calcite & 0.43 & $\mathrm{CaCO}_{3}$ \\
\hline & Dolomite & 0.96 & $\mathrm{CaMg}\left(\mathrm{CO}_{3}\right)_{2}$ \\
\hline & Goethite & 6.63 & $\mathrm{FeOOH}$ \\
\hline & Haematite & 15.43 & $\mathrm{Fe}_{2} \mathrm{O}_{3}$ \\
\hline & K-mica & 4.49 & $\mathrm{KAl}_{3} \mathrm{Si}_{3} \mathrm{O}_{10}(\mathrm{OH})_{2}$ \\
\hline & Kaolinite & 1.54 & $\mathrm{Al}_{2} \mathrm{Si}_{2} \mathrm{O}_{5}(\mathrm{OH})_{4}$ \\
\hline & Quartz & 0.09 & $\mathrm{SiO}_{2}$ \\
\hline \multirow{13}{*}{$\begin{array}{l}\text { Vranjska Banja } \\
\text { (VG-2) }\end{array}$} & Anorthite & 0.12 & $\mathrm{CaAl}_{2} \mathrm{Si}_{2} \mathrm{O}_{8}$ \\
\hline & Aragonite & 0.72 & $\mathrm{CaCO}_{3}$ \\
\hline & Ca-Montmorillonite & 0.00 & $\mathrm{Ca}_{0.165} \mathrm{Al}_{2.33} \mathrm{Si}_{3.67} \mathrm{O}_{10}(\mathrm{OH})_{2}$ \\
\hline & Calcite & 0.83 & $\mathrm{CaCO}_{3}$ \\
\hline & Chlorite(14A) & 5.55 & $\mathrm{Mg}_{5} \mathrm{Al}_{2} \mathrm{Si}_{3} \mathrm{O}_{10}(\mathrm{OH})_{8}$ \\
\hline & Dolomite & 0.34 & $\mathrm{CaMg}\left(\mathrm{CO}_{3}\right)_{2}$ \\
\hline & Gibbsite & 0.30 & $\mathrm{Al}(\mathrm{OH})_{3}$ \\
\hline & Goethite & 6.44 & $\mathrm{FeOOH}$ \\
\hline & Haematite & 15.14 & $\mathrm{Fe}_{2} \mathrm{O}_{3}$ \\
\hline & Illite & 0.00 & $\mathrm{~K}_{0.6} \mathrm{Mg}_{0.25} \mathrm{Al}_{2.3} \mathrm{Si}_{3.5} \mathrm{O}_{10}(\mathrm{OH})_{2}$ \\
\hline & K-mica & 6.25 & $\mathrm{KAl}_{3} \mathrm{Si}_{3} \mathrm{O}_{10}(\mathrm{OH})_{2}$ \\
\hline & Kaolinite & 1.61 & $\mathrm{Al}_{2} \mathrm{Si}_{2} \mathrm{O}_{5}(\mathrm{OH})_{4}$ \\
\hline & Quartz & -0.02 & $\mathrm{SiO}_{2}$ \\
\hline \multirow{14}{*}{$\begin{array}{l}\text { Vranjska Banja } \\
\text { (VG-3) }\end{array}$} & Anorthite & 0.26 & $\mathrm{CaAl}_{2} \mathrm{Si}_{2} \mathrm{O}_{8}$ \\
\hline & Aragonite & 0.89 & $\mathrm{CaCO}_{3}$ \\
\hline & Ca-Montmorillonite & 0.06 & $\mathrm{Ca}_{0.165} \mathrm{Al}_{2.33} \mathrm{Si}_{3.67} \mathrm{O}_{10}(\mathrm{OH})_{2}$ \\
\hline & Calcite & 0.99 & $\mathrm{CaCO}_{3}$ \\
\hline & Chlorite(14A) & 6.19 & $\mathrm{Mg}_{5} \mathrm{Al}_{2} \mathrm{Si}_{3} \mathrm{O}_{10}(\mathrm{OH})_{8}$ \\
\hline & Chrysotile & 0.14 & $\mathrm{Mg}_{3} \mathrm{Si}_{2} \mathrm{O}_{5}(\mathrm{OH})_{4}$ \\
\hline & Dolomite & 0.65 & $\mathrm{CaMg}\left(\mathrm{CO}_{3}\right)_{2}$ \\
\hline & Gibbsite & 0.28 & $\mathrm{Al}(\mathrm{OH})_{3}$ \\
\hline & Goethite & 5.85 & $\mathrm{FeOOH}$ \\
\hline & Haematite & 13.96 & $\mathrm{Fe}_{2} \mathrm{O}_{3}$ \\
\hline & Illite & 0.11 & $\mathrm{~K}_{0.6} \mathrm{Mg}_{0.25} \mathrm{Al}_{2.3} \mathrm{Si}_{3.5} \mathrm{O}_{10}(\mathrm{OH})_{2}$ \\
\hline & K-mica & 6.29 & $\mathrm{KAl}_{3} \mathrm{Si}_{3} \mathrm{O}_{10}(\mathrm{OH})_{2}$ \\
\hline & Kaolinite & 1.60 & $\mathrm{Al}_{2} \mathrm{Si}_{2} \mathrm{O}_{5}(\mathrm{OH})_{4}$ \\
\hline & Quartz & 0.00 & $\mathrm{SiO}_{2}$ \\
\hline
\end{tabular}

Positive SI were calculated for the following minerals from the mineral water samples from Vranjska Banja (wells VG-2 and VG-3): calcite and aragonite; iron oxides and hydroxides; and kaolinite. These minerals were also identified by optical assessment of the encrustation samples. The hydrogeochemical model suggested the possibility of precipitation of muscovite and chlorite from the water, the presence of which in the encrustations was corroborated by X-ray testing of the sample from well VG-3. However, it should be noted that the petrographic-mineralogic analysis revealed that this sample also contained part of the parent rock. Mild supersaturation with dolomite and gibbsite was not confirmed. Quartz was virtually in a state of equilibrium with water in this case as well (negative SI, but close to zero).

Based on macroscopic and optical assessments of the encrustations from the threelocations, the conclusion was that the encrustations originated from the water solution, through precipitation of calcite, laminar development, and varying degrees of staining with iron hydroxides. The silicate minerals could have been attached in the development process, particularly phyllosilicates (sericite and clay minerals), but the possibility of contamination during sampling should not be excluded. However, the positive SI of the silicate minerals in the mineral water samples from all three locations tend to suggest that they were attached during the precipitation of encrustations.

According to MULLIN (2001), BREZONIK \& ARNOLD (2011) and RICHARDS (2016), carbonate precipitation begins with nucleation in the mineral water solution. Colliding ions, oriented in a certain way, initiate the creation of a crystalline structure, forming carbonate encrustations that gradually become a continuous layer. The nucleation process can be primary or secondary. Primary nucleation refers to original carbonate precipitates, which did not pre-exist in the solution. Secondary nucleation is the growth of existing carbonate encrustations.

The Langelier Saturation Index (SILang) (2) and Ryznar Stability Index (SIRyz) (4) were used to test the stability of the mineral waters at Bogatić, Lukovska Banja and Vranjska Banja (Tab. 4).

$$
\begin{gathered}
\text { SILang }=\mathrm{pH}-\mathrm{pHs}, \\
\mathrm{pHs}=9.92-\frac{t}{40}-\log \left[\mathrm{Ca}^{2+}\right]-\log \left[\mathrm{HCO}_{3}{ }^{-}\right]+0.2 \log [\mathrm{S} . \mathrm{O} .], \\
\text { SIRyz }=2 \mathrm{pHs}-\mathrm{pH},
\end{gathered}
$$

where:

SILang - Langelier Stability Index,

SIRyz - Ryznar Stability Index,

$\mathrm{pH}-$ measure of hydrogen ion $\left(\mathrm{H}^{+}\right)$activity in solution,

$\mathrm{pHs}-\mathrm{pH}$ at which the water is saturated with calcium carbonate,

t - groundwater temperature $\left({ }^{\circ} \mathrm{C}\right)$,

$\mathrm{Ca}^{2+}-$ calcium concentration $(\mathrm{mg} / \mathrm{L})$,

$\mathrm{HCO}_{3}{ }^{-}$- bicarbonate concentration $(\mathrm{mg} / \mathrm{L})$,

S.O. - dry residue $(\mathrm{mg} / \mathrm{L})$.

These two indices consider water solely from the standpoint of the balance between concentrations of the following components: carbonates and bicarbonates, on one hand, and carbonic acid on the other (DEBERRY, 1982).

Table 4. Langelier Saturation Index (SILang) and Ryznar Stability Index (SIRyz) (ŠARABA et al., 2017).

\begin{tabular}{ccccc}
\hline Well & pH & pHs & SILang & SIRyz \\
\hline BB-1 & 6.9 & 6.2 & 0.7 & 5.5 \\
LB-4 & 7.5 & 6.6 & 0.9 & 5.7 \\
LB-5 & 6.6 & 6.4 & 0.2 & 6.2 \\
VG-2 & 7.9 & 6.2 & 1.7 & 4.5 \\
VG-3 & 8.0 & 6.1 & 1.9 & 4.2 \\
\hline
\end{tabular}

Legend: BB-1 - well in Bogatić; LB-4, LB-5 - wells in Lukovska Banja; VG-2, VG-3 - wells in Vranjska Banja. 
SILang can only be used to predict the ability of water to precipitate dissolved calcium carbonate, not calcium sulfate or calcium phosphate (MAJKIĆ-DURSUN et al., 2016). SIRyz is suitable for moderately hard to hard waters, but not soft or brackish waters. Even though the use of these indices is widespread, they can only approximate the stability of mineral waters (DEBERRY, 1982).

SIRyz $<7$ indicates precipitation of encrustations, SIRyz $>9$ that the predominant process is corrosion, and $7<$ SIRyz $<9$ that both, precipitation of encrustations and corrosion, are possible (RYZNAR, 1994). All of the studied occurrences of mineral water are characterized by SIRyz $<7$ (Tab. 4), which indicates that the precipitation of encrustations is the predominant process on wellheads and within the zones of emergence.

SILang values greater than zero in the case of the three studied mineral water occurrences (Tab. 4) indicate calcium carbonate precipitation on all the wells. Based on SIRyz values (Tab. 4), the mineral waters of wells BB-1, LB-4 and LB-5 tend to precipitate calcium carbonate because $\operatorname{SIRyz} \geq 5.5$, while $\operatorname{SIRyz}<5.5$ (wells VG-2 and VG-3) suggests that the mineral water at Vranjska Banja has an exceptional propensity for calcium carbonate precipitation.

SILang can also be used to determine the rate of encrustation. If SILang $<0.5$, then the rate of encrustation is up to $0.2 \mathrm{~g} /$ $\mathrm{m}^{2} \mathrm{~h}$; if $0.5<$ SILang $<1$, then 0.2 to $0.5 \mathrm{~g} / \mathrm{m}^{2} \mathrm{~h}$; and if SILang $>1$, then it is greater than $0.5 \mathrm{~g} / \mathrm{m}^{2} \mathrm{~h}$ (LANGELIER, 1936; VUKOVIĆ \& SORO, 1992).

According to the values of SILang in Tab. 3, the mineral water from well LB-5 belongs to the first category (encrustation rate $0.2 \mathrm{~g} / \mathrm{m}^{2} \mathrm{~h}$, SILang $<0.5$ ), the mineral water from wells BB-1 and LB-4 to the second category (rate from 0.2 to $0.5 \mathrm{~g} / \mathrm{m}^{2} \mathrm{~h}, 0.5<$ SILang $<1$ ), and the mineral water from wells VG-2 and VG-3 to the third category (rate higher than $0.5 \mathrm{~g} / \mathrm{m}^{2} \mathrm{~h}$, SILang $<0.5$ ).

According to MOROZOV \& MERSHCHII (1979), mineral waters characterized by SIRyz $<9$, SILang $>0$ and $\mathrm{Fe}^{3+}<0.3 \mathrm{mg} / \mathrm{L}$ will likely precipitate calcium and magnesium compounds, with $\mathrm{CaCO}_{3}$ being predominant. All the studied occurrences measured $\mathrm{Fe}^{3+}$ less than $0.3 \mathrm{mg} / \mathrm{L}$ (wells: BB-1 $-0.17 \mathrm{mg} / \mathrm{L}$; LB-4 -0.23 $\mathrm{mg} / \mathrm{L}$; LB-5 - $0.07 \mathrm{mg} / \mathrm{L} ; \mathrm{VG}-2-0.20 \mathrm{mg} / \mathrm{L} ; \mathrm{VG}-3-<0.10 \mathrm{mg} / \mathrm{L}$ ) (Tab. 2), and SILang $>0$ and SIRyz $<9$ (Tab. 4), which corroborated the predominant carbonate composition of the analyzed encrustations.

\subsection{Phototrophic microbial mats}

It is well known that many microorganisms, including phototrophic ones, can contribute to the precipitation of minerals on some surfaces. Thus, the encrustations can be affected by the formation of phototrophic biofilms, which can lead to the creation and accumulation of minerals in several ways. Cyanobacteria, for example, can incorporate different particles into their sheaths, among which carbonate minerals are the most common (WHITTON, 2012). Sheaths are mostly composed of extracellular polymeric substances (EPS), highly organized polymers that accumulate outside the cell forming a matrix with multiple roles (SECKBACH \& OREN, 2010). The most common role is the protection of the microorganism's cell from various harsh conditions. Harsh conditions are mostly high or low temperatures, UV radiation, changes in environmental chemistry, desiccation, predators, etc. According to many researchers, the most important role of EPS is its water retention capability and protection from desiccation.
The binding ability of EPS is certainly very useful and an interesting feature (WHITTON, 2012). EPS is capable of binding different particles, but also nutrients that can be of importance for biofilm functioning. Mineral precipitation often occurs within the EPS, rather than on the surface of cyanobacterial sheaths (SECKBACH \& OREN, 2010). Uronic acids play the main role in EPS. These charged groups are capable of interacting with sediment particles and it is believed that they can be involved in the regulation of the calcification process. Extracellular layers are particularly favourable sites for nucleation, and cyanobacterial species that produce sheaths or EPS generally precipitate more calcium carbonate than species without sheaths (WHITTON, 2012).

The analysis of phototrophic biofilms in this study was performed using scanning electron microscopy. Light microscopy in ŠARABA et al. (2017) provided an insight into the diversity of phototrophic microorganisms but scanning electron microscopy enabled more detailed analysis and allowed that the sample surface and morphology, the shape and size of different biofilm constituents, and their orientation, distribution and the way of attachment to be explored. By using this technique, we wanted to highlight the samples where EPS was present or dominant or where some mineral particles were visible and attached to EPS.

The presence of the three dominant algal divisions in the phototrophic biofilms was recorded, including Chlorophyta, Cyanobacteria and Bacillariophyta (ŠARABA et al., 2017) (Fig. 10), where Cyanobacteria, especially non-heterocytous trichal forms, were dominant in biofilm samples from all the localities.

The SEM micrographsof phototrophic biofilms (Figs. 10a, b, $\mathrm{d}$, e below) show the developed layer of extracellular polymeric substances (EPS). In general, mineral deposits attached to EPS are visible in the form of small particles, but also large particles (e.g. Fig. 10a). SEM analysis of biofilm samples from Bogatić mainly revealed the domination of trichal Cyanobacteria that were densely entangled and embedded in the extracellular matrix covered with different mineral particles (Figs. 10c and 10d). Trichal Cyanobacteria were also visible in the sample from Lukovska Banja (Fig. 10c), but representatives of Bacillariophyta were also present. In this sample, EPS was not as developed as in the samples from Bogatić. Particles of different origin were noted in EPS from Vranjska Banja (Fig. 10e), along with Bacillariophyta representatives. According to the micrographs, biofilm was highly developed and Cyanobacteria abundant in samples from Bogatic and Lukovska Banja (less abundant in Vranjska Banja).

Cyanobacteria (when phototrophic microorganisms are considered) can play an important role in the formation of encrustrations. For example, according to PEDLEY (1992), PERRY (1999) and RIDING (2000), laminar carbonate encrustations, generally wavy, in combination with phototrophic biofilm, are a result of carbonate silt and fine sediment trapped by the microbial populations. Recent encrustations, such as those sampled in this research, generally contained alternating organic and inorganic laminae. While the organic laminae were composed of different species of Cyanobacteria, inorganic laminae comprised carbonate silt, which Cyanobacteria had captured from the water.

Besides the capability of EPS to attach different particles, the microorganisms themselves can induce mineral precipitation. Phototrophic microbial matsare characterized by temporal and spatial dynamics and highly diverse metabolic pathways in the creation of minerals. During the day, photosynthesis and its organic products in the surface layer of the biofilm are the main factors of the origin of mineral precursors (metabolic fixation of inorganic carbon tends to increase the $\mathrm{pH}$ of the solution and lead 

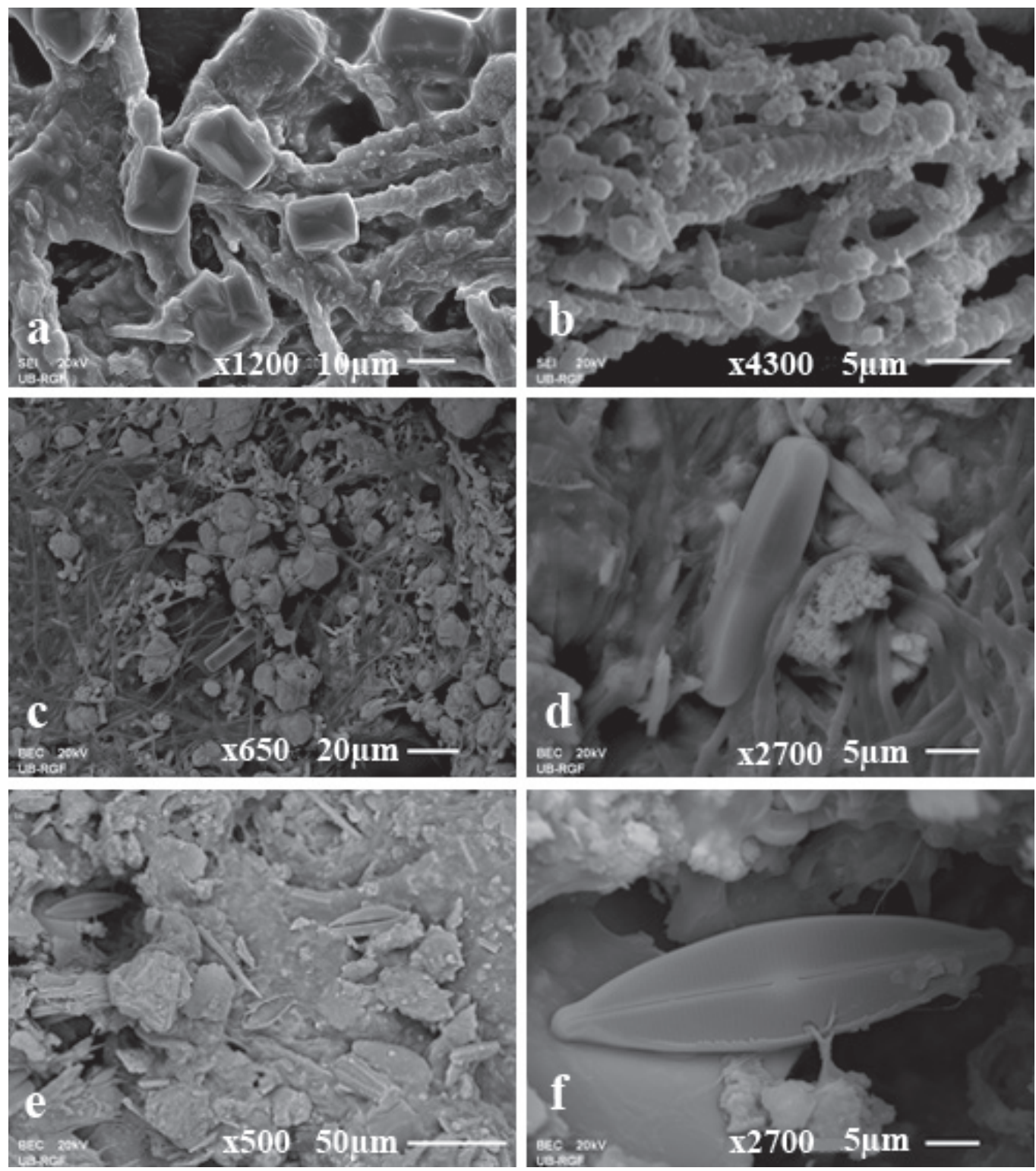

Figure 10. SEM micrographs of Cyanobacteria and phototrophic biofilm algae.

Legend: a, b. Bogatić (trichal Cyanobacteria embedded in EPS covered with particles of different origin); c, d. Lukovska Banja (trichal Cyanobacteria and Bacillariophyta); e, f. Vranjska Banja (Bacillariophyta representatives visible on both micrographs).

to a state of carbonate supersaturation). On the other hand, at night, during respiration, totally different micro conditions are created (lower $\mathrm{pH}, \mathrm{O}_{2}$, higher $\mathrm{CO}_{2}$, and the like), where products of respiration can dissolve minerals. In addition, the stratification of phototrophic microbial mats that is common in biofilms near thermal springs and the coexistence and cooperative metabolism of a large number of microorganisms can lead to the creation of diverse minerals in a small space, depending on the hydrochemical characteristics of the mineral water and environmental conditions. Due to their anoxygenic photosynthetic ability in the presence of $\mathrm{H}_{2} \mathrm{~S}$, Cyanobacteria can survive in extreme environments where many algae cannot live. The product of this process, elemental sulphur, can be deposited in the form of fine granules on the filament surface, which is no longer oxidized except in the presence sulfur oxidizing bacteria. Therefore, if calcium is present in high concentrations, they can facilitate the formation of various morphotypes of gypsum minerals (EDINGER, 1973; TANG et al., 2014; KAŹMIERCZAK et al., 2015).

\subsection{Implications}

The studied occurrences of mineral water definitely deserve special attention in the future, including the establishment of permanent monitoring, which would, inter alia, track the condition of steel wellheads and zones of emergence of mineral water, which are ideal substrates for encrustation and biofouling. The life manifestations of phototrophic mats come with different well ageing symptoms and they contribute to encrustation, among other things. Preemptive action indicated by monitoring would help avoid the need for well rehabilitation, which is costly. The wells would thus be maintained in a state of maximum productivity. Spending would be minimized, mineral water would be used for heating and health-and-recreation purposes without interruption, and the quality of the mineral water would be sustained, with no adverse effect on its organoleptic properties.

In addition, many of the identified phototrophic microorganisms are able to generate medicinal and economically-significant products and can be used by the biotechnological industry as a 
source of vitamins, enzymes, lactic acid and other substances of relevance to agriculture and medicine (ŠARABA et al., 2017).

The present study shows that the examined mineral waters, regardless of their extremely high temperatures and specific physical and chemical compositions, support the development of various microbial communities and constitute a starting point for studying thermal habitats, which to the present day remain uninvestigated biotopes, at least in Serbia. There is also the need to protect the environment and the genetic diversity of such habitats.

Moreover, encrustations are significant because they have a serious impact on the life cycle of a well, as it reduces the well's capacity, threatens the integrity of its structural components (Fig. 3), and changes the organoleptic properties of the mineral water, causing foul odour, unpleasant taste, turbidity etc., (HOUBEN \& TRESKATIS, 2007). The research conducted in Lukovska Banja and Vranjska Banja corroborated that the well in Bogatic is not a solitary case of encrustation coupled with biofouling.

A large number of wells have encrustation issues. The water industry has been aware of the problem for more than 100 years (HOWSAM et al., 1995; de ZWART, 2007; STERRETT et al., 2008; DEED \& PREENE, 2015). Preventative measures require an in-depth understanding of the processes, which the present research attempted to explain using examples of carbonate encrustations.

\section{CONCLUSION}

The study conducted from 2014 to 2017 revealed that in Serbia there are sources of mineral water that exhibit numerous specific features with regard to their basic ionic composition, temperature, total dissolved solids, $\mathrm{pH}$, and the like.

Encrustations were noted at all study locations (Bogatić, Lukovska Banja and Vranjska Banja), on wellheads and within zones of mineral water emergence. The results of macroscopic and optical assessments, as well as X-ray powder diffraction, indicated a predominantly calcium carbonate composition of the encrustations, with calcite and aragonite detected at all the locations. Quartz, albite, muscovite and clinochlore were also detected at some of the locations.

The study concluded that the physico-chemical composition of the mineral waters was a key driver of the onset and progress of encrustation. High water temperatures $\left(>60^{\circ} \mathrm{C}\right)$, $\mathrm{pH}$ levels from 6.6 to 8.0, elevated TDS - from 600 to $1267 \mathrm{mg} / \mathrm{L}$, and the dominance of the $\mathrm{HCO}_{3}{ }^{-}$ion $(361.6-598.0 \mathrm{mg} / \mathrm{L})$, along with a certain proportion of the $\mathrm{Ca}^{2+}$ ion $(12.8-83.2 \mathrm{mg} / \mathrm{L})$, favour the formation of carbonate encrustations. In addition, the concentration of $\mathrm{CO}_{2}$ in the mineral waters $\left(50.5-194.2 \mathrm{mg} / \mathrm{L}\right.$ free $\left.\mathrm{CO}_{2}\right)$ is also important, as it contributes to carbonate precipitation by disturbing the carbonate balance in the mineral water solution.

In addition, hydrogeochemical modeling confirmed that there was a correlation between the chemical composition of the mineral waters and the mineral composition of the encrustations or, in other words, that the minerals detected in the encrustations likely originated from the mineral waters.

Prognostic analyses corroborated a propensity for encrustation at all locations, given that all the studied occurrences of mineral water were characterized by SIRyz $<7$ and SILang $>0$, indicating carbonate encrustations.

Apart from encrustations, phototrophic microbial mats were found at all the sites, represented by Cyanobacteria, Chlorophyta and Bacillariophyta, which, inter alia, can facilitate the creation, accumulation of minerals in encrustations, indirectly affecting the rate of carbonate precipitation.

\section{ACKNOWLEDGEMENT}

The Serbian Ministry of Science has financially supported this research under contracts TR33053, OI176020 and OI176018.

\section{REFERENCES}

APPELO, C.A.J. \& POSTMA, D. (1994): Geochemistry, Groundwater and Pollution ( $2^{\text {nd }}$ ed.).- Balkema Publishers, Rotterdam, $635 \mathrm{p}$.

APPELO, C.A.J. \& POSTMA, D. (2004): Geochemistry, Groundwater and Pollution.CRC Press, London, 683 p.

ARNÓRSSON, E. (1989): Deposition of calcium carbonate minerals from geothermal waters. Theoretical considerations.- Geothermics, 18/1-2, 33-39. doi: 10.1016/ 0375-6505(89)90007-2

BREZONIK, P. \& ARNOLD, W. (2011): Water chemistry: an introduction to the chemistry of natural and engineered aquatic systems.- Oxford University Pres, USA, $765 \mathrm{p}$.

BROWN, K.L. (2013): Mineral scaling in geothermal power production.- United Nations University.

BUHMANN, D. \& DREYBRODT, W. (1987): Calcite dissolution kinetics in the system $\mathrm{H}_{2} \mathrm{O}-\mathrm{CO}_{2}-\mathrm{CaCO}_{3}$ with the participation of foreign ions.- Chemical Geology, 64/1-2, 89-102. doi: 10.1016/0009- 2541(87)90154-9.

BUIK, N.A. \& WILLEMSEN, G. (2006): Clogging rate of recharge wells in porous media.- Proceedings Megastock, Pomona, NJ, USA.

CHAFETZ, H.S. \& FOLK, L. (1984): Travertines: depositional morphology and the bacterially constructed constituents.- J. Sediment. Res., 54, 289-316.

CHAFETZ, H.S. (1994): Bacterially induced precipitates of calcium carbonate and lithification of microbial mats.- Biostabilization of sediments, 149-163.

de ZWART, A.H. (2007): Investigation of clogging processes in unconsolidated aquifers near water supply wells.- Ponaen \& Looyen BV, Delft.

DEBERRY, D.W. (1982): Corrosion in potable water systems.- US Environmental Protection Agency, Office of Drinking Water, Final Report, Austin, Texas, USA.

DEED, M.E.R. \& PREENE, M. (2015): Managing the clogging of groundwater wells.Proceedings of the XVI ECSMGE, Geotechnical Engineering for Infrastructure and Development, 2787-2792. doi:10.1680/ecsmge.60678

DEMIR, M., BABA, A., ATILLA V. \& INANLI, M. (2014): Types of the scaling in hyper saline geothermal system in northwest Turkey.- Geothermics, 50, 1-9. doi: 10.1016/j.geothermics.2013.08.003

DOLGORJAV, O. (2009): Geochemical characterization of thermal fluids from the Khangay area, Central Mongolia.- Geothermal training programme reports, Orkustofnun, Grensásvegur, p. 9.

DONLAN, R.M. (2002): Biofilms: microbial life on surfaces.- Emerging infectious diseases, 8/9, 881-890. doi: 10.3201\%2Feid0809.020063

DRAGIŠIĆ, V. \& POLOMČIĆ, D. (2009): Hidrogeološki rečnik.- University in Belgrade, Faculty of Mining and Geology, Serbia.

DRISCOLL, F.G. (1986): Groundwater and Wells (2nded.).- Johnson Filtration Systems Inc., St. Paul.

EDINGER, S.E. (1973): An investigation of the factors which effect the size and growth rates of the habit faces of gypsum.- Journal of Crystal Growth, 18/3, 217-224. doi: 10.1016/0022-0248(73)90164-4

FILIPOVIĆ, B. (2003): Mineralne, termalne i termomineralne vode Srbije.- University in Belgrade, Faculty of Mining and Geology, Serbia, 1-278.

FILIPOVIĆ, B., KRUNIĆ, O. \& LAZIĆ, M. (2005): Regionalna hidrogeologija Srbije.University in Belgrade, Faculty of Mining and Geology, Serbia, 401 p.

FLÜGEL, E. (2004): Microfacies of Carbonate Rocks.- Springer Berlin Heidelberg, New York, 117-242. doi: 10.1007/978-3-662-08726-8 5

FLÜGEL, E. (2013): Microfacies of carbonate rocks: analysis, interpretation and application. - Springer Science \& Business Media, 1-976.

GARCIA, A.V., THOMSEN, K. \& STENBY, E.H. (2005): Prediction of mineral scale formation in geothermal and oilfield operations using the extended UNIQUAC model: Part I. Sulfate scaling minerals.--Geothermics, 34/1, 61-97. doi: 10.1016/j. geothermics.2004.11.002

GALLUP, D.L. (2002): Investigation on of organic inhibitors for silica scale control in geothermal brines.- Geothermics, 31/4, 415-430. doi: 10.1016/S0375-6505(02) 00004-4

GAVRILKO, V.M. \& ALEKSEEV, V.S.S. (1985): Water wells screen.- Publishing House Nedra, Moscow, 300-304.

GILL, J.S. (1998): Silica scale control.- Chem. Treatment, 41-45.

GUNNLAUGSSON, E. \& EINARSSON, J. (1989): Magnesium-silicate scaling in mixture of geothermal water and deaerated fresh water in a district heating system.Geothermics, 18/1-2, 113-120. doi: 10.1016/0375-6505(89)90017-5

GUNNlAugSSON, E., ÁrmannSSON, H., THORHALSSON, S. \& STEINRÍMSSON, B. (2014): Problems in geothermal operation - scaling and corrosion.Goethermal Training Program, United Nations University, 1-18. 
GUO, L. \& RIDING, R. (1992): Aragonite laminae in hot water travertine crusts, Rapolano Terme, Italy.-Sedimentology, 39/6, 1067-1079. doi: 10.1111/j.1365-3091.1992. tb01997.x

HONEGGER, J.L., CZERNICHOWSKI-LAURIOL, I., CRIAUD, A., MENJOZ, A., SAINSON, S. \& GUEZENNEC, J. (1989): Detailed study of sulfide scaling at la courneuuenord, a geothermal exploitation of the Paris Basin, France.- Geothermics, 18/1-2, 137-144. doi: 10.1016/0375-6505(89)90020-5

HOUBEN, G. (2000): Genesis, aging and chemical removal of well incrustations.-Applied Mineralogy in Research, Economy, Technology, Ecology and Culture, 2, 803-806.

HOUBEN, G. (2001): Well ageing and its implications for well and piezometer performance.- IAHS publication, 297-302.

HOUBEN, G.J. (2006): The influence of well hydraulics on the spatial distribution of well incrustations.- Groundwater, 44/5, 668-675. doi: 10.1111/j.1745-6584.2006.00216.x

HOUBEN, G. \& TRESKATIS, C. (2007): Water well rehabilitation and reconstruction.McGraw-Hill.

HOUBEN, G.J. \& WEIHE, U. (2010): Spatial distribution of incrustations around a water well after 38 years of use.- Groundwater, 48/1, 53-58. doi: 10.1111/j.1745-6584.2009.00641.x

HOWSAM, P., MISSTEAR, B. \& JONES, C. (1995): Monitoring, maintenance and rehabilitation of water supply boreholes.- Construction Industry Research and Information Association.

JEMCEV, V. \& ĐUKIĆ, D. (2000): Mikrobiologija.- Vojnoizdavački zavod, Belgrade, $759 \mathrm{p}$.

JONES, B. \& RENAUT, R.W. (2010): Calcareous spring deposits in continental settings.- Development in Sedimentology, 61/4, 177-224. doi: 10.1016/S00704571(09)06104-4

JURÁNEK, J., ŠKOLLOVA, Z. \& HARNOVÁ, J. (1987): "MINEQUA" Part I. A program for computing the chemistry of calcium carbonate in mineralized and thermal waters.- Geothermics, 16/3, 263-270. doi: 10.1016/0375-6505(87)90005-8

KAŹMIERCZAK, J., FENCHEL, T., KUHL, M., KEMPE, S., KREMER, B., LACKA, B. \& MALKOWSKI, K. (2015): $\mathrm{CaCO}_{3}$ precipitation in multilayered cyanobacterial mats: clues to explain the alternation of micrite and sparite layers in calcareous stromatolites.- Life, 5/1, 744-769. doi: 10.3390/life5010744

KRISTMANNSDÓTTIR, H. (1989): Types of scaling occurring by geothermal utilization in Iceland.- Geothermics, 18/1-2, 183-190. doi: 10.1016/03756505(89)90026-6

KRUNIĆ, O. (1999): Termomineralne vode Srbije - osnovni tipovi i karakteristike.- PhD Thesis, University in Belgrade, Faculty of Mining and Geology, Serbia.

KRUNIĆ, O. (2012): Mineralnevode-- University in Belgrade, Faculty of Mining and Geology, Serbia, 1-384.

LANGELIER, W.F. (1936): The analytical control of anti-corrosion water treatment.Journal of American Water Works Association, 28/10, 1500-1521. doi: 10.1002/ j.1551-8833.1936.tb13785.x

LAWRENCE, J.R. \& CALDWELL, D.E. (1987): Behavior of bacterial stream populations within the hydrodynamic boundary layers of surface microenvironments.Microbial Ecology, 14/1, 15-27. doi: 10.1007/BF02011567

LAZIĆ, M. (2004): Metode razrade i regeneracije bunara.- University in Belgrade, Faculty of Mining and Geology, Serbia, 1-236.

LI, B. \& LOGAN, B.E. (2004): Bacterial adhesion to glass and metal-oxide surfaces.Colloids and Surfaces B: Biointerfaces, 36/2, 81-90. doi: 10.1016/j.colsurfb.2004.05.006

MAJKIĆ, B. (2013): Starenje bunara u aluvijalnim sredinama različitog stepena oksičnosti.- PhD Thesis, University in Belgrade, Faculty of Mining and Geology, Serbia.

MAJKIĆ-DURSUN, B., PETKOVIĆ, A. \& ZDRAVKOVIĆ-BORELI, Đ. (2016): Potencijal korozivnosti aluvijalnih podzemnih voda u slivu Velike Morave.-Zaštita Materijala, 57/3, 404-411. doi: 10.5937/ZasMat1603404M

MARTINOVIĆ, M. \& MILIVOJEVIĆ, M. (1998): The hydrogeothermal system of Mačva and Semberija.- In: Geothermie: Forshung Entwicklung Markt (Tagungsband). Geothermische Fachtagung, Straubing, 5, 133-141.

MARTINOVIĆ, M. (2012): Mogućnost proizvodnje električne energije iz hidrogeotermalnih resursa na području surduličkog granitoidnog masiva.- In: XIV Serbian Symposium of Hydrogeology with International Participation, May 17-20, Zlatibor. University in Belgrade, Faculty of Mining and Geology, Belgrade, 203-209.

MILIVOJEVIĆ, M. (1989): Evaluation of geothermomineral resources of Serbia territory-excluding autonomous provinces.- $\mathrm{PhD}$ Thesis, University of Belgrade, Faculty of Mining and Geology, Serbia.

MITIĆ, N., STOJILJKOVIĆ, D., TODOROVIĆ, Ž., NIKOLIĆ, LJ., STOJILJKOVIĆ, S. \& CAKIĆ, S. (2014): Physicochemical and geochemical characterization of geothermal waters sedimentation tendency at Sijarinska spa and Vranjska spa (Serbia).- Hem. Ind. 68 /1, 63-67. doi: 10.2298/HEMIND121002026M

MOROZOV, E.A. \& MERSHCHII, V.A. (1979): Соодужение и эксплуатация водозаборных скважин.- Budivelnyk, Kijev.

MULLIN, J.W. (2001): Crystallization.-- Elsevier, 587 p.
NOFFKE, N., ERIKSSON, K.A., HAZEN, R.M. \& SIMPSON, E.L. (2006): A new window into Early Archean life: Microbial mats in Earth's oldest siliciclastic tidal deposits (3.2 Ga Moodies Group, South Africa).- Geology, 34/4, 253-256. doi: $10.1130 / \mathrm{G} 22246.1$

OGINO, T., SUZUKI, T. \& SAWADA, K. (1987): The formation and transformation mechanism of calcium carbonate in water-- Geochemica et Cosmochimica Acta, 51/10, 2757-2767. doi: 10.1016/0016-7037(87)90155-4

ÖLÇENOĞLU, K. (1986): Scaling in the reservoir in Kizildere Geothermal Field, Turkey.- Geothermics, 15/5-6, 731-734. doi: 10.1016/0375-6505(86)90085-4

PAPIĆ, P. (1999): Inkrustacione i agresivne osobine mineralnih voda Srbije.- PhD Thesis, University of Belgrade, Faculty of Mining and Geology, Serbia.

PARKHURST, D.L. \& APPELO, C.A.J. (1999): User's guide to PHREEQC (Version 2): A computer program for speciation, batch-reaction, one-dimensional transport, and inverse geochemical calculations.- Denver, Colorado: U. S. Geological Survey.

PÁTZAY, G., KÁRMÁN, H.F. \& PÓTA, G. (2003): Preliminary investigations of scaling and corrosion in high enthalpy geothermal wells in Hungary.- Geothermics, 32/4-6, 627-638. doi: 10.1016/S0375-6505(03)00068-3

PEDLEY, M. (1992): Freshwater (phytoherm) reefs: the role of biofilms and their bearing on marine reef cementation.- Sedimentary Geology, 79/1-4, 255-274. doi: 10.1016/0037-0738(92)90014-I

PERDIKOURI, C., KASIOPTAS, A., GEISLER, T., SCHMIDT, B.C. \& PUTNIS, A. (2011): Experimental study of the aragonite to calcite transition in aqueous solution.- Geochemica et Cosmochimica Acta, 75/20, 6211-6224. doi: 10.1016/j. gca.2011.07.045

PERRY, C.T. (1999): Biofilm-related calcification, sediment trapping and constructive micrite envelopes: a criterion for the recognition of ancient grass-bed environments?- Sedimentology, 46/1, 33-45. doi: 10.1046/j.1365-3091.1999.00201.x

PLUMMER, L.N., WIGLEY, T.M.L. \& PARKHURST, D.L. (1978): The kinetics of calcite dissolution in $\mathrm{CO}_{2}$ water systems at 5 degrees to 60 degrees $\mathrm{C}$ and 0.0 to 1.0 atm $\mathrm{CO}_{2 .-}$ American Journal of Science, 278/2, 179-216. doi: 10.2475/ ajs.278.2.179

PLUMMER, L.N. \& BUSENBERG, E. (1982): The solubilitites of calcite, aragonite and vaterite in $\mathrm{CO}_{2}-\mathrm{H}_{2} \mathrm{O}$ solutions between 0 and $90^{\circ} \mathrm{C}$, and an evaluation of the aqueous model for the system $\mathrm{CaCO}_{3}-\mathrm{CO}_{2}-\mathrm{H}_{2} \mathrm{O}$.- Geohemica Cosmochimica Acta, 46/6, 1011-1040. doi: 10.1016/0016-7037(82)90056-4

POTAPOV, V.V., KASHPURA, V.N. \& ALEKSEEV, V.I. (2001): A study of the growth of deposits in geothermal power systems.- Therm. Eng., 48/5, 395-400.

PROTIĆ, D. (1995): Mineralne i termalne vode Srbije.- Geoinstitute, Belgrade, Serbia, $1-269$.

RICHARDS, C.S. (2016): Calcium Carbonate Formation in Water Distribution Systems and Autogenous Repair of Leaks by Inert Particle Clogging.- PhD thesis, Virginia Tech.

RIDING, R. (2000): Microbial carbonates: the geological record of calcified bacterial algal mats and biofilms.- Sedimentology, 47, 179-214. doi: 10.1046/j.1365-3091.2000.00003.x

RYZNAR, J.W. (1994): A new index for determining amount of calcium carbonate scale formed by a water.- J. Am. Water Works Assoc., 36/4, 472-486.

SCHNIEDERS, J.H. (2003): Chemical cleaning, disinfection and decontamination of water wells.- Johnson Screens, 227 p.

SCHWANKL, L., HANSON, B. \& PRICHARD, T. (2008): Maintaining microirrigation systems.- UCANR Publications (Vol. 216137)

SECKBACH, J. \& OREN, A. (2010): Microbial mats: modern and ancient microorganisms in stratified systems.- Springer Science and Business Media, Vol. 14. doi: 10.1007/978-90-481-3799-2

STERRETT, R., MEHMERT, M. \& HANNA (2008): Twenty years in the water well industry: where are we? - Groundwater, 46/5, 659-659. doi: 10.1111/j.1745-6584.2008.00460.x

STOJILJKOVIĆ, D., CAKIĆ, S. \& MITIĆ, N. (2015): Stvaranje depozita u instalacijama sa geotermalnom vodom, tretman geotermalne vode elektromagnetskim poljem promenljive učestanosti u cilju sprečavanja stvaranja depozita.- Faculty of Technology, University in Niš.

SZEWZYK, U. \& SCHINK, B. (1988): Degradation of hydroquinone gentisate and benzoate by a fermenting bacterium in pure or defined mixed culture.- Journal of Arch. Microbiol., 151/6, 541-545.

ŠARABA, V., POPOVIĆ, S., KRUNIĆ, O., SUBAKOV SIMIĆ, G., KLJAJIĆ, Ž. \& LAZIĆ, M. (2017): Mineral waters of Serbia and development of phototrophic microbial communities near points of emergence and on wellheads.-Acta Carsologica, 46/2-3, 295-316. doi: 10.3986/ac.v46i2-3.4961

TANG, M., EHRRESIER, A. \& LI, Y. (2014): Gypsum in modern Kamchatka volcanic hot springs and the Lower Cambrian black shale: Applied to the microbial-mediated precipitation of sulfates on Mars.-American Mineralogist, 99/10, 2126-2137. doi: 10.2138/am-2014-4754

TICE, M.M. \& LOWE, D.R. (2006): Hydrogen-based carbon fixation in the earliest known photosynthetic organisms.-Geology, 34/1,37-40. doi: 10.1130/G22012.1 
TIŠLJAR, J. (2001): Sedimentologija karbonata i evaporita.- Institut za geološka istraživanja, Zagreb, 375 p.

VAN BEEK, K., BREEDVELD, R., TAS, M. \& KOLLEN, R. (2010): Prevention of Wellbore Clogging by Intermittent Abstraction.- Groundwater Monitoring and Remediation, 30/4, 81-89. doi: 10.1111/j.1745-6592.2010.01307.x

VAN BEEK, C.K. (2011): Cause and prevention of clogging of wells abstracting groundwater from unconsolidated aquifers.- IWA Publishing, 1-143.
VUKOVIĆ, M. \& SORO, A. (1992): Hydraulics of water wells: theory and application.Water Resources Pubblications.

WHITTON, B.A. (2012): Ecology of cyanobacteria II: their diversity in space and time.Springer Science and Business Media.

WOYESSA, A.O. (2012): Identification of Hydrochemical Processes in the Screen Environment in Shallow Geothermal Wells from Gardermoen.- Unpubl. Master Thesis, University of Oslo, Faculty of Mathematics and Natural Sciences. 